\title{
The Corporate Governance Obsession
}

\author{
Mariana Pargendler*
}

September 2014

\begin{abstract}
It is hard to overstate the preeminence of corporate governance in the contemporary academic and policy debates. For a variety of economic and social problems - from economic development and systemic risk to rising inequality and gender inequity corporate governance reform has surfaced as a favored policy response. This Article traces the origins, examines the political preconditions, and scrutinizes the implications of the obsession with corporate governance as a solution to a constellation of economic and social ills.

The central claim is that the ascent of the corporate governance movement coincided with, and ultimately substituted for, the retreat of government in the last decades. And, ironically, it did so by treating the corporation as a metaphor for government and by transposing to the corporate context the framework and remedies typical of government, such as "checks and balances" and democracy. The compromise character of the corporate governance agenda explains its political palatability and resilience: it appeals to progressives as a path for social and economic change in the face of political resistance to greater state intervention, while pleasing conservative forces as an acceptable concession to deflect greater governmental intrusion in private affairs.

Although the costs and benefits of specific corporate governance practices have been the object of an extensive literature, the driving forces and general merits of this relentless emphasis on corporate governance have received much less attention. Any careful normative assessment of the corporate governance obsession must consider not only the effects specific corporate governance practices but also the extent to which such proposals crowd out the policy space. The Article then concludes by speculating on the future of the corporate governance obsession.
\end{abstract}

\footnotetext{
* Visiting Professor of Law, Stanford Law School (2014-2015); Professor of Law, Fundação Getulio Vargas Law School (FGV Direito SP); Global Associate Professor of Law, New York University School of Law. I am grateful to Ronald Gilson, Henry Hansmann, Jed Kroncke, John Morley, Katharina Pistor, Roberta Romano, and Bruno Salama for very helpful comments on an earlier version of this draft. All errors are my own.
} 


\section{Introduction}

Corporate governance has become a constant fixture of the academic and policy debates of our time. ${ }^{1}$ It not only figured prominently in the Sarbanes-Oxley Act of 2002 and the Dodd-Frank Act of 2010, the sweeping regulatory reforms of the last decade, but its reach has been far broader at both domestic and international levels. For a vast array of economic and social problems - from economic development ${ }^{2}$ and systemic risk $^{3}$ to rising inequality ${ }^{4}$ and gender inequity ${ }^{5}$ - corporate governance reform has surfaced as a favored policy response. As evidence of its popularity in academic circles, by early 2014 there were over 10,000 papers on the website of the Social Sciences Research Network (SSRN) that make explicit reference to "corporate governance" in their title or abstract, up from about 3,500 in $2006 .^{6}$

It has not always been this way. On the contrary, the view that the internal governance of the corporation plays a fundamental role in social welfare is of relatively recent vintage. The very expression "corporate governance" did not even exist in English language until the 1970s. ${ }^{7}$ The appearance of this new terminology is not fortuitous, but rather indicative of a new mindset: one which assumes that the particular balance of power, organizational structure, and decision-making processes within the corporation matters deeply for economic outcomes.

This essay traces the origins, examines the political preconditions, and scrutinizes the implications of the obsession with corporate governance as a solution to a constellation of economic ills. The ascent of the corporate governance movement in the United States since the late 1970s coincided with the wave of deregulation and

\footnotetext{
${ }^{1}$ Stijn Claessens \& Burcin Yurtoglu, Corporate Governance and Development: An Update, 10 Focus 1, 1 (2012) (noting that while "the term corporate governance meant little to all but a handful of scholars and shareholders" only two decades ago, "[t]oday, it is a mainstream concern—a staple of discussion in corporate boardrooms, academic roundtables, and policy think tanks worldwide”); Lucian A. Bebchuk \& Michael Weisbach, The State of Corporate Governance Research, 23 REV. FIN. STUD. 939, 939 (2010) ("Interest in corporate governance has been rapidly growing, both inside and outside academia, together with recognition of its importance”); Mats Isaksson \& Serdar Çelik, Who Cares? Corporate Governance in Today's Equity Markets 7, OECD Corporate Governance Working Papers No. 8, 2013 ("corporate governance is a hot policy topic").

${ }^{2}$ See Claessens \& Yurtoglu, supra note 1 (for a review of the literature on the relationship between corporate governance and development). See also Charles P. Oman, Corporate Governance in Development: The Concept, the Issues, the Policies Challenges 25, in CORPORATE GOVERNANCE IN Development: The Experiences of Brazil, Chile, India, AND South AFRICA 25 (Charles P. Oman ed., 2003).

${ }^{3}$ OECD STEERING GROUP ON CORPORATE GOVERnANCE, THE CORPORATE GOVERNANCE LESSONS FROM THE FINANCIAL CRISIS (2009).

${ }^{4}$ See Section II.E(i) infra.

5 See, e.g., Press Release, European Commission, Cracking Europe's Glass Ceiling: European Parliament Backs Commission's Women on Boards Proposal, Nov. 20, 2013.

${ }^{6}$ The 2014 figures are based on the author's search on the website www.ssrn.com. For the 2006 data, see the review article by Stuart L. Gillan, Recent Developments in Corporate Governance: An Overview, 12 J. CORP. FIN. 381, 381 (2006).

${ }^{7}$ Disseminated since the 1990s, the somewhat awkward foreign translations of the English expression (gouvernement d'entreprise, gobernanza corporativa, governança corporativa) are of even more recent vintage.
} 
distrust of government action. The thrust of my argument is that such overlap was not accidental. In an era marked by growing skepticism of government intervention ("government is not the solution to our problem; government is the problem," Ronald Reagan's famous slogan went), the cure for economic woes had to lie in the private sector.

If government was increasingly regarded as the problem, corporate governance emerged as an attractive solution. As in a hydraulic system, governance substituted for government. Corporate governance became a form of privatization, devolving to the private sector the policymaking and oversight functions typical of government. Figure 1 - which plots the incidence of the terms "corporate governance" and "government regulation" in books over time - underscores this point by showing a clear inverse relationship between the usage of both terms over time.

Figure 1. Google books Ngram Viewer: government regulation (red) vs. corporate governance (blue)

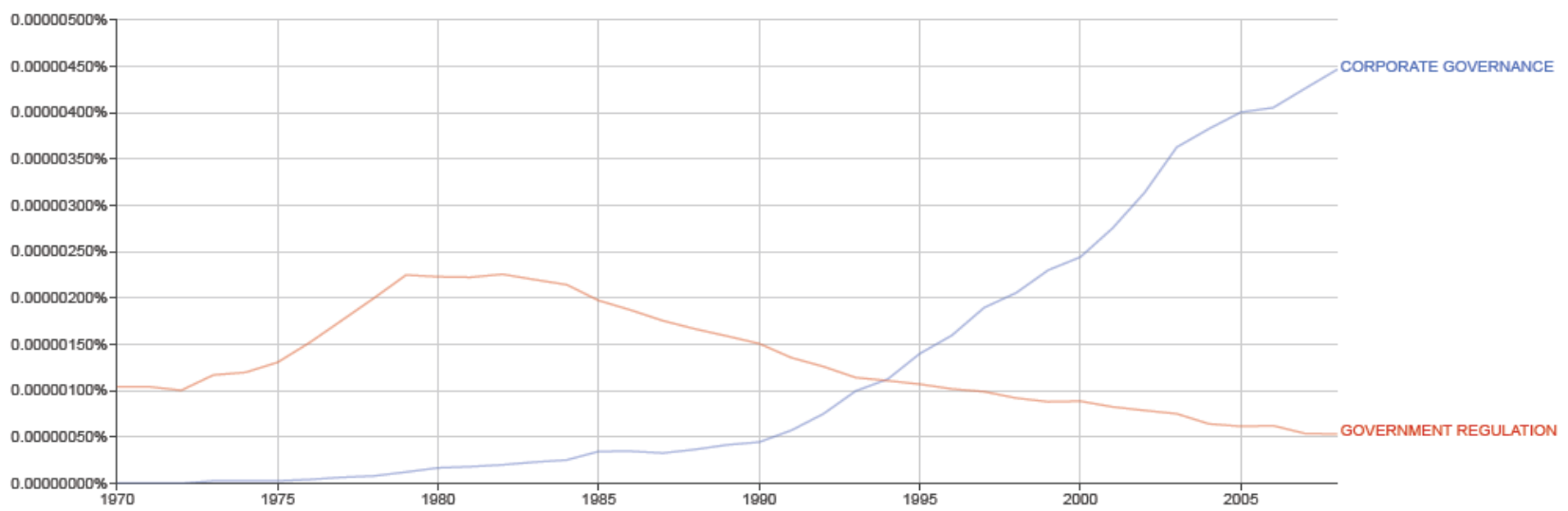

The growing concern with corporate governance thus became a partial surrogate for the retreat of public governance in the policy arena. ${ }^{8}$ And, ironically, it did so by treating the corporation as a metaphor for government. The resulting obsession with corporate governance rests on three pillars: (i) the recognition of the economic import of corporations and the comparative impotence of government; (ii) the application to the corporate form of the framework and solutions typical of government control (such as "checks and balances” and democracy); and (iii) the presumed relevance of the internal

\footnotetext{
${ }^{8}$ For a similar argument applied specifically to the financial industry, see Brian Cheffins, The Corporate Governance Movements, Banks and the Financial Crisis (ECGI Working Paper No. 232, 2014), http://ssrn.com/abstract=2365738 (explaining “corporate governance's emergence and staying power by reference to changing market conditions and a deregulation trend that provided executives with unprecedented managerial discretion as the $20^{\text {th }}$ century drew to a close"). While "governance" first gained traction in the corporate context, it then spread to other areas as well, as in "global governance." See Matthew Eagleton-Pierce, On the Genesis of the Concept of 'Governance': A Post-Bureaucratic Perspective (Working Paper, 2011).
} 
balance of power within the corporation to social welfare. The implicit promise of the corporate governance solution is that, once the proper decision-making processes are in place, external regulation of corporate action will become increasingly superfluous, as corporations will be best positioned to govern themselves.

So understood, the corporate governance agenda turned out to be particularly palatable from a political perspective. It is, after all, a compromise solution that simultaneously combines a private sector focus with a reformist overtone. As such, corporate governance change appeals to progressives as a path for social and economic change in the face of political resistance to greater state intervention, while pleasing conservative forces as an acceptable concession to deflect greater governmental intrusion in private affairs. The apparent surge in the levels of stock ownership by U.S. households since the 1980s only bolstered this delicate equilibrium by seemingly approximating social welfare to measures of stock market performance in a "society of shareholders." 9

Based on this framework, corporate governance movement withstood the test of time in the face of the changing nature of the problems it sought to address. When it first made an appearance in the 1970s, corporate governance was a response to then dominant concerns about corporate failures and unbridled corporate power, as epitomized by corruption scandals and overt violations of law. In the 1980s, corporate governance proposals were restyled as a remedy against economic complacency and underperformance vis-à-vis Germany and Japan, then booming economies with markedly different systems of corporate organization. In the 1990s, as the U.S. economy recovered, the Anglo-Saxon model of corporate governance turned into a blueprint for financial and economic development around the world, particularly in emerging markets and transition economies. After the turn of the millennium, corporate governance reform surfaced once again at the top of the policy agenda, first as a reaction to the corporate scandals of this new era (as evidenced by the financial debacle of Enron, WorldCom and the like), and then as a response to the global financial crisis of 2008. More recently, corporate governance became the focal point of the central social debates of our time, from the rise of income inequality to human rights violations and the stagnation of gender progress.

Although the costs and benefits of specific corporate governance practices have been the object of an extensive literature in law, economics, and finance, ${ }^{10}$ the driving forces and general merits of this obsession with corporate governance have received much less attention. In a recent paper, Marcel Kahan and Edward Rock have argued that the actual stakes in various corporate governance controversies are trivial and hardly justify the intensity of the debate. ${ }^{11}$ In this respect, I suggest that even if the benefits of sound corporate governance practices were considerable, they could still be insufficient to justify the ever-greater role of corporate governance in public policy in lieu of other

\footnotetext{
${ }^{9}$ See notes 184-187 infra and accompanying text.

${ }^{10}$ The literature is evidently too voluminous to be cited in full. For a non-exhaustive review of prominent issues, see Bebchuk \& Weisbach, supra note 1.

${ }^{11}$ Marcel Kahan \& Edward Rock, Symbolic Corporate Governance Politics 1 (Working Paper, 2014), http://papers.ssrn.com/sol3/papers.cfm?abstract_id=2404530.
} 
mechanisms to restrain corporate conduct. Any serious evaluation of the merits of this corporate governance obsession must take into account not only the effect of the proposed policies but also the extent to which they crowd out more promising modes of intervention.

Before proceeding to the core of the Article, a few caveats are in order. The narrative that follows approaches the growing obsession with corporate governance from an intellectual history standpoint. In striving to situate the dominant driving forces and themes in each period, it privileges analytical clarity at the cost of oversimplification. This is emphatically not to deny that there were - and still are dissonant and critical views on the corporate governance solution at every step of the way, in particular by those who either deny that there is a problem or crisis to begin with, or who trust market forces to solve it. ${ }^{12}$

Moreover, by focusing on the evolution of the corporate governance movement in the realm of ideas and public policies, the analysis presented here addresses only incidentally the key underlying economic conditions that made the corporate governance solution viable. Although these considerations are critically important, they are not exactly uncharted territory.

A prominent example of this line of inquiry is Jeffrey Gordon's work attributing the rise of independent directors in the United States to the greater informativeness of stock market prices - which, he argued, made it possible for outsiders to monitor the pursuit of shareholder value for corporate management. ${ }^{13}$ Ronald Gilson, in turn, ascribes the transformation in U.S. corporate governance in the last decades of the twentieth century to changes in the operation of product markets as well as capital markets. ${ }^{14}$ There is also a well-established connection between calls for greater shareholder involvement in corporate governance and the drastic expansion of institutional (as opposed to individual) ownership of corporate stock since the midtwentieth century. ${ }^{15}$ Relatedly, the gradual shift in pension systems from defined benefit to defined contribution plans has tied the fortune of workers to the performance of stock

\footnotetext{
${ }^{12}$ For an early critique of the corporate governance movement, see Daniel R. Fischel, The Corporate Governance Movement, 35 VAND. L. REv. 1259 (1982) (arguing that "critics have leveled charges and proposed solutions to a problem that does not exist"). For a more recent work in this spirit, see JonATHAN Macey, Corporate Governance: Promises Kept, Promises Broken (2008) (repudiating most policies traditionally associated with the corporate governance movement, such as independent boards, and praising market-based solutions to agency problems, such as the market for corporate control).

${ }^{13}$ Jeffrey N. Gordon, The Rise of Independent Directors in the United States, 1950-2005: Of Shareholder Value and Stock Market Prices, 59 STAN. L. REV. 1465, 1474 (2007).

${ }^{14}$ Ronald J. Gilson, Catalysing Corporate Governance: The Evolution of the United States System in the 1980s and 1990s, 24 COMPANY \& SEC. L.J. 143, 147-149 (2006)

${ }^{15}$ See, e.g., Brian R. Cheffins, The History of Corporate Governance, in OXFORD HANDBOOK OF CORPORATE GOVERnANCE 46, 52 (Mike Wright et al. eds, 2013). Cheffins notes that "the proportion of shares in U.S. public companies institutional investors owned rose from 16\% in 1965 to $47 \%$ in 1987 and again to $57 \%$ in 1994," which, in turn, made them increasingly logical contenders to play a major corporate governance role since the 1980s. Id. See also Ronald J. Gilson \& Jeffrey N. Gordon, The Agency Costs of Agency Capitalism: Activist Investors and the Revaluation of Governance Rights, 113 COLum. L. REV. 863 (2013) (discussing the implications of the rise of institutional ownership to up to $70 \%$ of the outstanding shares of the largest U.S. firms).
} 
markets, hence increasing popular interest in corporate governance and legitimizing the pursuit of shareholder wealth maximization. ${ }^{16}$

Finally, and perhaps more importantly, is the fact that corporate governance change did not result from the invisible hand of the market alone. It was instead brought about by the visible hand and voice of policy entrepreneurs advocating for corporate governance reform in its different stripes. ${ }^{17}$ There is, in fact, an observed disjunction between economic forces and corporate governance policy. Not only is the link between certain corporate governance best practices and desired outcomes tenuous in many instances, ${ }^{18}$ but the corporate governance movement is premised on the notion that market forces alone do not lead companies to adopt optimal corporate governance practices. $^{19}$

The remainder of this essay proceeds in five parts. Part I describes the birth and continuing rebranding of the corporate governance movement to address a shifting array of problems through its different phases up to the present. Part II examines the structural and political factors that explain the rise and persistence of the corporate governance solution over time. Part III then addresses the merits and shortcomings of this obsession with corporate governance from a public policy and social welfare standpoint. Part IV concludes by speculating on the future of the corporate governance obsession.

\section{The Rise of Corporate Governance}

Despite its extensive usage, there is no canonical definition of what "corporate governance" means. ${ }^{20}$ Understood as the amalgam of responses to the agency problems

\footnotetext{
${ }^{16}$ See Martin Gelter, The Pension System and the Rise of Shareholder Primacy, 43 Seton Hall L. Rev. 909 (2013).

17 The contemporaneous emergence of a corporate governance industry only accentuates the selfreinforcing character of the corporate governance agenda. Kahan \& Rock, supra note 11, at 28. Take the example of Robert Monks, self-described as an "entrepreneur for the idea of corporate governance." While at the Department of Labor, he prompted the enactment of a policy initiative requiring pension funds to vote the shares held. After leaving government for the private sector, Monks founded Institutional Investor Services (ISS), a proxy advisory firm whose business is to provide voting advice to institutional investors. Cheffins, supra note 15, at 53.

${ }^{18}$ For a forceful demonstration of this point, see Roberta Romano, The Sarbanes-Oxley Act and the Making of Quack Corporate Governance, 114 YALE L. J. 1521 (2005) (documenting the large literature suggesting that the corporate governance mandates introduced by the Sarbanes-Oxley Act were unlikely to be effective).

${ }^{19}$ See, e.g., for works suggesting that private contracting alone is unlikely to produce optimal corporate governance arrangements, Michael Klausner, Fact and Fiction in Corporate Law and Governance, 65 StAN. L. Rev. 1325, 1326 (2013) (reviewing the extant literature and concluding that, on balance, the empirical evidence is not supportive of the proposition that "market forces promote optimal corporate governance arrangements, independent of law"); Lucian A. Bebchuk, Asymmetric Information and the Choice of Corporate Governance Arrangements, Harvard Law School Olin Discussion Paper 398 (2001), http://ssrn.com/abstract=327842 (arguing that asymmetric information leads to the enactment of suboptimal corporate governance practices).

20 Prominent attempts at conceptualizations range from the overly technical to more intuitive formulations, be they narrower or broader in scope. See, e.g., Luigi Zingales, Corporate Governance. NBER Working Paper 6309 (1997), at 4, available at
} 
and legitimacy issues that plague business corporations, corporate governance issues are as old as the corporate form itself - and perhaps even older, if ancient functional substitutes to the corporate form are taken into account. ${ }^{21}$ Not surprisingly, there is an abundance of studies on corporate governance topics broadly understood from a historical perspective, covering conflicts between shareholders and managers that date back at least to the East India companies of the seventeenth century. ${ }^{22}$

As employed throughout this essay, the meaning of corporate governance is, however, narrower. The focus lies on internal corporate governance, which relates to the balance of power between shareholders, boards of directors, and managers. ${ }^{23}$ Although critically important, external corporate governance - which refers to external constraints over corporate behavior, such as those provided by credit markets, competition, and the market for corporate control - is left out of the present analysis. ${ }^{24}$ Such exclusion is not arbitrary, however, for most policy efforts have favored solutions linked to internal governance over those that rely on market forces, such as the market for corporate control. ${ }^{25}$

For our purposes, as in Richard Cyert's pioneering articulation of the concept in a 1976 U.S. Senate hearing, corporate governance "deals with the relationship of a board of directors to the chief executive officer and to the stockholders of the

http://papers.ssrn.com/sol3/papers.cfm?abstract_id=46906 (defining corporate governance as "the ways in which suppliers of finance to the corporations assure themselves of getting a return on their investment”); Andrei Shleifer \& Robert Vishny, A Survey of Corporate Governance, 52 J. Fin. 737, 737 (1997) (referring to "the ways in which suppliers of finance to the corporations assure themselves of getting a return on their investment”); OECD, OECD PRINCIPLES OF CORPORATE GOVERNANCE 11 (1999) [hereinafter OECD Principles of Corporate Governance] (alluding to "a set of relationships between a company's management, its board, its shareholders and other stakeholders," as well as "the structure through which the objectives of the company are set, and the means of attaining those objectives and monitoring performance are determined"). At one extreme is the overly broad conception of corporate governance as "[a]nything and everything that influences the way that a corporation is actually run." MACEY, supra note 12, at 2.

${ }^{21}$ See, e.g., Adam Smith's famous warning against the "agency problems" plaguing the corporate form. 3 AdAm Smith, The Wealth of NAtions 116-17 (P.F. Collier \& Son 1909) (1776). For a functional review of the predecessors to the corporate form in ancient Rome and the Middle Ages, see Henry Hansmann, Reinier Kraakman \& Richard Squire, Law and the Rise of the Firm, 119 HARV. L. ReV. 1333 (2006).

${ }^{22}$ See, e.g., A History OF CORPORATE GOVERnANCE AROUND THE WORLD (Randall Morck ed., 2005) (for a collection of historical studies on corporate ownership); ORIGINS OF SHAREHOLDER ADVOCACY (Jonathan G.S. Koppell ed., 2011) (compiling studies on shareholder protests against managerial abuse since the Dutch and English East India Companies of the sixteenth century).

${ }^{23}$ In current usage, corporate governance is also at times deemed to encompass the role of other private sector gatekeepers, such as auditors, lawyers, consultants, and rating agencies. Although these debates are left out of our exposition for simplicity purposes, the key tenets of the obsession with corporate governance apply to them well.

${ }^{24}$ For the distinction between internal and external corporate governance, see Il Chong Nam, Yeongjae Kang \& Joon-Kyung Kim. Comparative Corporate Governance Trends in Asia, in CoRPORATE GOVERNANCE IN ASIA 85 (OECD); OECD, CORPORATE GOVERNANCE OF NON-LISTED COMPANIES IN EMERGING MARKETS (2006).

${ }^{25}$ MACEY, supra note 12, at 10 ("the most effective corporate governance mechanism, the market for corporate control, has been the subject of an intense regulatory backlash”). 
corporation in general." ${ }^{26}$ As more recently enunciated in the OECD Principles of Corporate Governance, corporate governance "relates to the internal means by which corporations are operated and controlled." ${ }^{27}$ The corporate governance solution posits that improvements in the balance of power internal to the business corporation matters a great deal for economic and social outcomes.

Viewed in these terms, there is no perfect overlap between the corporate governance solution and the reduction of agency costs. Corporate governance is not the sole possible solution to agency problems, and agency problems are not the exclusive target of the corporate governance solution. ${ }^{28}$ Instead, both agency and other problems can be addressed by regulatory and governance strategies. ${ }^{29}$ Regulatory solutions consist of externally imposed rules and standards that seek to influence the substance of corporate action, such as fiduciary duties, prohibitions on certain insider loans, capital requirements for banks, and the sanctioning of corruption. The corporate governance solution, by contrast, relies on structures and procedures that merely shape the balance of power and decision-making processes within the corporate form, such as director independence requirements and shareholder voting rights.

The seminal contribution of Adolf Berle and Gardiner Means illustrates this distinction. In "The Modern Corporation and Private Property," first published in 1932, the authors offered a famous description of the agency problem afflicting the widelyheld corporations that populated U.S. capital markets. ${ }^{30}$ In view of the growing separation between ownership and control, they warned against the risk that corporate managers could run the firm without the interests of shareholders in mind. Yet the remedy favored by Berle and Means was distinctively not a corporate governance solution as here defined. They did not argue for checks and balances within the corporation through changes in the internal division of power. Instead, they advocated for a non-governance response premised on external regulatory constraints: specifically, by expanding corporate disclosure ${ }^{31}$ and by strengthening fiduciary duties so as to treat managers as veritable "trustees.",32

Berle and Means's neglect for the corporation's internal governance was not accidental. The impotency of the corporation's internal forces as a meaningful check on abuse was part and parcel of their model. On the one hand, the highly dispersed and

\footnotetext{
${ }^{26}$ Corporate Rights and Responsibilities: Hearings before the Committee on Commerce, United States Senate, Ninety-Fourth Congress, Second Session (Jan. 1, 1976); William Ocasio \& John Joseph, Cultural adaptation and institutional change: The evolution of vocabularies of corporate governance, 1972-2003, 33 POETICS 163, 167 (2005).

${ }^{27}$ OECD, OECD PRINCIPLES OF CORPORATE GOVERNANCE 7 (1999).

${ }^{28}$ See Section II.E infra.

${ }^{29}$ John Armour, Henry Hansmann \& Reinier Kraakman, Agency Problems and Legal Strategies, in THE ANATOMY OF CORPORATE LAW 39 (Reinier Kraakman et al. eds, 2009) [hereinafter ANATOMY] (distinguishing between regulatory and governance strategies to address agency problems).

${ }^{30}$ AdOlPh Berle \& Gardiner MeAns, THe Modern CORPORATION \& PRIVATE Property (Transaction Publishers, 1991) (1932). The expression "agency costs" is however newer, dating back to the work of Jensen and Meckling. Michael C. Jensen \& William H. Meckling, Theory of the Firm: Managerial Behavior, Agency Costs, and Ownership Structure, 3 J. FIN. ECON. 305 (1976).

${ }^{31}$ BERLE \& MEANS, supra note 30, at 284.

${ }^{32}$ Id. at 242 (suggesting that "corporation law become[s] in substance a branch of the law of trusts").
} 
disorganized shareholders of widely held corporations had little incentive and clout to exercise corporate influence in their account - a condition they viewed as inevitable. ${ }^{33}$

On the other hand, their analysis largely failed to distinguish between the roles of directors and officers, for the most part alluding to both categories under the single rubric of "management." 34 This should not be entirely surprising, since directors and officers were mainly the same people in the insider-dominated boards prevalent at the time. ${ }^{35}$ It is, however, clear that such overlap offered little hope that the board would operate as a meaningful check on management. In fact, throughout Berle and Means's work, unchecked managerial power lay with corporate directors, not with an allpowerful CEO, as came to be the case in later diagnoses. ${ }^{36}$

Berle and Means played a part in the enactment of the Securities and Exchange Acts of the early 1930s, which primarily relied on mandatory disclosure to inform entry and exit ${ }^{37}$ decisions by investors - essentially a non-governance solution. ${ }^{38}$ Similarly, other contemporaneous pieces of legislation, such as the Glass Steagall Act of 1933 and the Investment Company Act of 1940, also sought to constrain corporate conduct from without, in fact disabling the role of institutional investors as a meaningful check on corporate management. ${ }^{39}$ In any case, Berle and Means’s work failed to trigger a lasting

33 See id. at 47 ("Dispersion in the ownership of separate enterprises appears to be inherent in the corporate system. It has already proceeded far, it is rapidly increasing, and appears to be an inevitable development); and id. at 83 ("For the most part the stockholder is able to play only the part of the rubber stamp”).

${ }^{34}$ See, e.g., id. at 196 (elaborating on the legal position of management).

${ }^{35}$ Gordon, supra note 13, at 1474 (showing that the proportion of independent directors on U.S. public company boards rose doubled from 35\% to 70\% between 1950 and 2005).

${ }^{36}$ Id. at 217 (alluding to a scenario "where 'control' is in the hands of the Board of Directors because stock is widely dispersed”).

37 A modest exception that proves the rule is Section 14(a) of the Exchange Act, which authorized the SEC to issue rules and regulations with respect to proxy solicitations. Whether these provisions allowed the SEC to encroach on the internal balance of power of corporations remains a controversial question. See Jill Fisch, From Legitimacy to Logic: Reconstructing Proxy Regulation, 46 VAND. L. REV. 1129, 1174 (1993) (claiming that while the drafters of the Exchange Act sought to reform the management of business corporations through greater shareholder participation, “[it] is unclear... whether the legislation adopted by Congress retained that objective”). See also Business Roundtable v. SEC, 905 F.2d 406, 411412 (D.C. Cir. 1990) (finding that the Commission lacked the authority to regulate the "distribution of voting power," as "proxy regulation bears almost exclusively on disclosure”). In any event, despite the SEC's exaltation of a "democratic view of the voting process," its regulations effectively "increased the costs of shareholder communication and coordinated action among shareholders," especially since the 1950s. John Pound, Proxy Voting and the SEC: Investor Protection Versus Market Efficiency, 29 J. FIN. ECON. 241, 241, 262 (1991) (for an excellent description of the historical evolution of the SEC proxy rules).

38 Admittedly, the original purpose of securities regulation in the United States also suffered a transformation over time, in developments that parallel the corporate governance obsession. Donald C. Langevoort \& Robert B. Thompson, "Publicness" in Contemporary Securities Regulation after the JOBS Act, 101 GEO. L. J. 337, 372-3 (2013) (arguing that securities regulation has become increasingly about "social, political, and economic interests, in addition to capital formation" since the late 1970s).

39 Mark Roe's influential account attributes the predominance of dispersed ownership structures in the U.S. to various legal constraints imposed as a result of populist politics based on anti-Wall Street sentiment. MARK J. RoE, Strong MANAgERS, WeAK OWners (1996). But see John Morley, Collective Branding and the Origins of Investment Fund Regulation, 6 VA. L.\& BUS. REV. 341 (2012) (arguing that 
interest in corporate law. By 1962, Bayless Manning declared that "corporation law, as a field of intellectual effort, is dead in the United States." 40 As Roberta Romano subsequently put it, until the late 1970s corporate law had become "an uninspiring field of research even to some of its most astute students.”41

If corporate law scholarship was dormant, the stage of economic theory during this period also militated against a focus on internal corporate governance. The business firm was famously treated as a "black box" by neoclassical economics, ${ }^{42}$ whereas organizational economics was still in its infancy. In 1937 Ronald Coase broke new ground by exploring the economic rationale for the existence of firms, but his findings were not taken up for decades. ${ }^{43}$ It was not until the 1970s that interest in what goes on inside the firm was reignited by the work of Oliver Williamson, Jensen and Meckling, and others. $^{44}$

Finally, the tardy emergence of the corporate governance obsession is also a function of the favorable economic conditions prevailing in the mid-twentieth century. ${ }^{45}$ The United States enjoyed an era of unique internal economic prosperity and stability in the post-War period. Reformist in nature, the corporate governance solution thrives in periods of crises. It is no coincidence that the movement emerged in the 1970s, when corporate failures, corruption scandals, and unfavorable macroeconomic conditions disrupted the previous economic equilibrium and created demand for institutional change.

\section{The Phases of the Corporate Governance Obsession}

\section{A. Problem \#1: Unbridled Corporate Power and Economic Failure}

The very expression "corporate governance" - as the defense of the corporate governance solution to which it was inextricably linked from the outset - first surfaced in the 1970s. Although the New York Times featured the phrase as early as 1972, it was not until 1976 that the concept acquired theoretical backing. ${ }^{46}$ That year marked both the publication of Ralph Nader et al.'s “Taming the Modern Corporation,” as well as the

mutual funds were already uninterested in activism prior to the advent of such regulations).

${ }^{40}$ Bayless Manning, The Shareholder's Appraisal Remedy: An Essay for Frank Coker, 72 YALE L.J. 223, 245 (1962).

${ }^{41}$ Roberta Romano, Metapolitics and Corporate Law Reform, 36 STAN. L. ReV. 923, 923 (1984). See also Oliver Williamson, Corporate Governance, 93 YALE L. J. 1197 (1984) (“After a long hiatus, the study of corporate governance has recently enjoyed a revival").

${ }^{42}$ Ronald H. Coase, Lecture to the Memory of Alfred Nobel (Nobel Prize Lecture): The Institutional Structure of Production, Dec. 9, 1991, http://www.nobelprize.org/nobel_prizes/economicsciences/laureates/1991/coase-lecture.html.

${ }^{43}$ Ronald H. Coase, The Nature of the Firm, 4 ECONOMICA 386 (1937); Ronald H. Coase, The Nature of the Firm: Influence, 4 J. L. ECON. \& ORG. 33 (1988) (remarking that “'The Nature of the Firm' had little or no influence for thirty or forty years after it was published").

${ }^{44}$ OliVer Williamson, MARKET AND HIERARCHIES (1975); Jensen \& Meckling, supra note 30.

${ }^{45}$ Eugene V. Rostow, To Whom and for What Ends is Corporate Management Responsible?, in THE CORPORATION IN MODERN SOCIETY 59 (Edward S. Mason ed., 1964) (1959) (writing in a period in which "[t]here seems to be no general conviction that reform is needed," as "business seems energetic").

${ }^{46}$ See supra note 26 and accompanying text. 
initial appearance of the term in the Federal Register. ${ }^{47}$

The first problem which corporate governance purported to address was the perception of unbridled "corporate power" and the ensuing need for "corporate accountability." 48 Two central events in the 1970s contributed to this diagnosis. The first was the unexpected debacle of the Penn Central Railroad, then regarded as "the bluest of blue chips" 49 of the time. The second was the illegal campaign contributions and foreign corruption incidents associated with the Watergate scandal. ${ }^{50}$

To be sure, suspicion of corporate power runs deep in U.S. history, not least due to the early association between the corporate form and monopoly power. ${ }^{51}$ From a historical perspective, the initial policy reaction was to restrict, and then later to liberalize, access to corporate charters in an era in which incorporations required prior governmental approval. Curiously, some of the early responses to corporate (market) power took the form of governance arrangements, such as voting caps and corporate purpose restrictions. $^{52}$ Nevertheless, as time went by, corporate law became increasingly narrow and specialized in the rights of shareholders, managers, and creditors. ${ }^{53}$ Concerns about corporate and market power became the object of distinct areas of law, such as antitrust and industry regulation. ${ }^{54}$

By the mid-1970s, however, the emerging view once again was that limitations on corporate power should come from within the corporate form. Rather than receiving further constraints by the government, the corporation could and should look more like government itself ${ }^{55}$ - and hence cure its apparent failings through internal checks on misconduct. From the left, reforming the corporation from within seemed to be the only feasible solution given the government's frailty in the face of ever increasing corporate power and the accompanying degree of political influence, which rendered futile other forms of regulation. ${ }^{56}$ From the right, internal governance reform appeared as a

${ }^{47} \mathrm{Id}$.

48 For a synthesis of this view, see Victor Brudney, The Independent Director - Heavenly City or Potemkin Village?, 95 HARV. L. REV. 597 (1981-1982)

${ }^{49}$ Gordon, supra note 13 , at 1515.

${ }^{50}$ Id.

${ }^{51}$ Citizens United v. Fed. Election Comm’n, 558 U.S. 310, 387 (2010) (Scalia, J., concurring) (“[m]ost of the Founders' resentment towards corporations was directed at the state-granted monopoly privileges that individually chartered corporations enjoyed”).

${ }^{52}$ Henry Hansmann \& Mariana Pargendler, The Evolution of Shareholder Voting Rights: Separation of Ownership and Consumption, 123 YALE L.J. 101 (2014) (arguing that a number of early nineteenthcentury U.S. corporations were, in essence, consumer cooperatives, and that voting caps and purpose descriptions specified in their charters served to protect the interests of shareholders qua consumers); HERBERT HOVENKAMP, ENTERPRISE AND AMERICAN LAW, 1836-1937 63 (1991) (describing the powerful antitrust features of early corporate charters).

${ }^{53}$ Hansmann \& Pargendler, supra note 52, at 145.

${ }^{54}$ Id.

${ }^{55}$ Cary Coglianese, Legitimacy and Corporate Governance, 32 DEL. J. CORP. L. 159 (2007) (arguing that "[p]erhaps more than ever before, corporate governance reforms bear much closer resemblance to institutional mechanisms typically found in government”). While Coglianese's account refers to the early 2000s, this phenomenon was conspicuous at least since the 1970s, as we shall see.

56 See, e.g., RALPH NADER, MARK GREen \& JOEL SEligman, TAMing the Giant Corporation 22 (1976) (drawing attention to the specter of government capture and the "unhealthy dependence by 
reasonable concession to deflect the specter of government intervention. ${ }^{57}$

Indeed, resort to the metaphor of the corporation qua government - and the related defense of mechanisms typical of government control - was pervasive across the political spectrum. At one extreme, in their progressive opus "Taming the Giant Corporation,” Ralph Nader, Mark Green, and Joel Seligman claimed that "[t]he modern corporation is akin to a political state in which all powers are held by a single clique" and suggested, after quoting James Madison in the Federalist No. 47, that "[t]hese are precisely the circumstances that, in a democratic political state, require a separation of powers into different branches of authority." 58

The same analogy between the corporation and government also permeated the discourse of conservative business associations. The Statement of the Business Roundtable of 1977 likewise relied on the Federalist papers and the "tripartite organization of the Federal Government" to address the "corporate governance triad of shareowners, directors, operating management." 59 The document expressly conceded that "the public and its elected representatives should be concerned that private business organizations like government itself be subject to checks and balances, to constraints on excessive power." 60

The essence of the corporate governance obsession - then as now - resides in the transposition to the corporate context of two time-honored mechanisms for constraining and legitimizing state power: “checks and balances” through separation of powers and democracy. In the corporate arena, the main actors in the tripartite separation of powers are shareholders, boards of directors, and managers. Yet managerial power, the perception went, had gone unchecked. An adequate system of checks and balances required strengthening the role of the board of directors and affording a meaningful role to shareholders - a recipe that would prove to be remarkably resilient to cope with a variety of economic problems for decades to come.

\section{Strengthening the board: independent directors and the monitoring function}

Revitalizing the role of the board of directors was from the outset the most popular and least controversial of the two goals. There was growing recognition that actual boardroom practice had failed to live up to the central role conferred on the board of directors by corporate law. Although the "law on the books" assigned to the board the job of "managing the business affairs of the business corporations," real-world directors fell far short of this ideal. ${ }^{61}$ Therefore, it was argued, directors ought to

government on business"). Daniel Fischel, who was openly hostile to the corporate governance movement, ascribed the left's embrace of corporate governance reform to its failure in the political arena. Fischel, supra note 12, at 1271 ("It appears that it is only because the proponents of reform have largely failed in implementing their objectives through the political processes that they have turned to attempting to achieve these same objectives by altering the governance of corporations”).

${ }^{57}$ See notes 59-60 infra and accompanying text.

${ }^{58} \mathrm{Id}$. at $118-9$.

59 Statement of the Business Roundtable, The Role and Composition of the Board of Directors of the Large Publicly Owned Corporation, 33 Bus. LAW. 2083, 2089 (1977-78).

${ }^{60} \mathrm{Id}$. at 2090.

61 See Myles Mace, Directors: Myth AND ReAlity (1971) (describing the limited advisory role 
transition from their historical roles as mere "pawns" of management to become effective monitors of corporate officers. In the terminology coined by Melvin Eisenberg, the imperative makeover was one from an advisory board to a "monitoring board."62

It was evident that such a transformation in the actual functioning of the board nonetheless required a corresponding change in board composition. Specifically, effective monitoring necessitated a certain level of distance and differentiation from management. The key, it seemed, was to replace corporate insiders with outside - and later, more forcefully, also independent - directors. ${ }^{63}$

Another companion policy to the rise of independent directors did not take long to surface: namely, the implementation of independent board leadership through a split in the positions of board chair and chief executive officer (CEO). ${ }^{64}$ The intuitive idea was that it did not make sense for the monitoring board in charge of overseeing the company's management to be led (and have its agenda controlled) by the person who was the main target of the monitoring efforts. These proposals shared a common spirit: as the state retreated, the promise of independent directors - as arbiters of adequate corporate performance of the private sector, by the private sector, and for the private sector - progressively gained ground.

The call for greater board independence gathered broad support, in part because of its political ambiguity. Social activists viewed independent directors as a suitable - if not ideal - mechanism to render corporate management more sensitive to the public interest. ${ }^{65}$ Other commentators, by contrast, regarded the rise of independent directors as perfectly consistent with the goal of maximizing shareholder wealth. ${ }^{66}$

In 1977, urged by the Securities and Exchange Commission (SEC), the New York Stock Exchange adopted a listing rule requiring audit committees to be composed of a majority of outside directors. ${ }^{67}$ The new rule came in the aftermath of the

played by the board of directors). MELVIN A. EISENBERG, THE STRUCTURE OF THE CORPORATION (1976) (arguing that the received legal model about the role of the board was inadequate from both a descriptive and a normative perspective.

${ }^{62}$ EISENBERG, supra note 61.

${ }^{63}$ Gordon, supra note 13.

${ }^{64}$ For a review of the history of this idea, see Millstein Ctr. for Corp. Governance \& Performance, Chairing the Board: The Case for Independent Leadership in Corporate North America 13 (2009).

${ }^{65}$ See, e.g., Victor Brudney, The Independent Director - Heavenly City or Potemkin Village?, 95 HARV. L. REV. 597 (1981-1982) ("Numerous observers have argued that the addition of independent directors to corporate boards would solve the problem of corporate social responsibility without incurring the costs of external regulation").

${ }^{66}$ Fischel, supra note 12, at 1282 ("Unlike the arguments for shareholder democracy, a plausible case can be made that boards dominated by independent directors will increase shareholders' welfare”). More recently, see Gordon, supra note 13, at 1469.

${ }^{67}$ In a letter addressed to the New York Exchange, the SEC Chairman urgest the Exchange to "take the lead in this area by appropriately revising its listing policies, thus providing a practical means of effecting these important objectives without increasing direct government regulation.” Letter from Roderick M. Hills to M. Balten (May 11, 1976), in Special Supplement, Report of the Securities and Exchange Commission on Questionable and Illegal Corporate Payments and Practices Submitted to the Senate Banking, Housing and Urban Affairs Committee (May 12, 1976) 
corruption scandals of the Nixon administration. The link between the corruption scandals and the policy response is revealing. Instead of relying solely (or primarily) on public law and government action, ${ }^{68}$ the promise of independent directors ran in the opposite direction. It was premised on the assumption that private sector checks and balances are the best cure for private sector ills.

Interestingly, even corporate managers - the constituency whose power independent directors were designed to curb - came to support the measure as a sensible private sector reform that crowded out more intrusive forms of government action. In the same statement in which the Business Roundtable warned that "both human liberty and economic efficiency depend heavily on limiting the power of the state," it supported the "tendency of U.S. corporations to move to a board structure based on a majority of outside directors" to further the board's role in carrying out "the effective performance of the economic functions of an enterprise and for meeting other responsibilities.”69

The rise of outside directors likely looked so palatable to business interests in view of the far more radical character of the alternative policy prescriptions floating around at that juncture. ${ }^{70}$ Proposals for federal corporate chartering proliferated rapidly, as did calls for revamping the board's role through the inclusion of constituency directors, with representatives of workers, consumers, or general representatives of the public interest. ${ }^{71}$ In this environment, the voluntary embrace of independent directors whose precise practical import was, and continues to be, dubious ${ }^{72}$ - was an attractive compromise.

Indeed, as the political climate cooled in subsequent years, the Business Roundtable abandoned its prior moderate position, and vigorously opposed the attempt

${ }^{68}$ To be sure, these scandals also triggered more interventionist regulatory responses, such as the enactment of the Foreign Corrupt Practices Act.

${ }^{69}$ Statement of the Business Roundtable, supra note 59, at 2089, 2093 and 2085. To be sure, the Roundtable's position that "[i]n most instances... it is desirable that the board be composed of a majority of non-management directors" was qualified by the usual caveat that "there will be exceptions [to a majority of outside directors] based on the particular situation of an enterprise." Id. at 2108. For a critique, see Myles L. Mace, Directors: Myth and Reality - Ten Years Later, 32 RuTGERS L. Rev. 293, 297-8 (1979). Yet the use of the argument that "one size does not fit all" to tone down proposed reforms has been a hallmark of the conservative approach to corporate governance debate ever since.

${ }^{70}$ See Lawrence A. Cunningham, Rediscovering Board Expertise: Legal Implications of the Empirical Literature, in Perspectives on Corporate Governance 62 (F. Scott Kieff \& Troy A. Paredes eds., 2010) (noting that the Business Roundtable opened its 1977 Statement endorsing outside directors "in fear").

71 NADER ET AL., supra note 56 (arguing for federal chartering of corporations and describing contemporary claims for constituency directors).

${ }^{72}$ For reviews of the empirical literature challenging the effectiveness of independent directors, see Sanjai Bhagat \& Bernard Black, The Uncertain Relationship between Board Composition and Firm Performance, 54 Bus. L. 921 (1999); Roberta Romano, Corporate Law and Corporate Governance, 5 InDUS. \& CORP. CHANGE 277 (1996); Sanjai Bhagat \& Bernard Black, The Non-Correlation between Board Independence and Long-Term Firm Performance, 27 J. CORP. L. 231, 267 (2002); Romano, supra note 18; Usha Rodrigues, The Fetishization of Independence, 33 J. CORP. L. 447 (2008). For a recent work arguing that the push for increased board independence is meant to deflect pressure for more meaningful regulatory reform, see Urska Velikonja, The Political Economy of Board Independence, 92 N.C. L. REV. 855 (2014). 
by the American Law Institute (ALI) to endorse a majority of independent directors. The Business Roundtable's change of heart was clearly driven by the different political environment of the Reagan era, which eliminated existing threats of federal regulation and, therefore, the need to make corporate governance concessions. ${ }^{73}$ In fact, in 1982 the Chairman of the Business Roundtable Task Force on Corporate Responsibility urged the Roundtable's members to oppose the ALI project by underscoring "its roots in the "70s as part of the effort to meet federal incorporation and similar proposals" and pointing out that "[i]f the effort to adopt that kind of legislation was unsuccessful in the halcyon days of the activists, it is difficult to regard that concern as having much validity now or, for that matter, in the foreseeable future." ${ }^{74}$

Nevertheless, the obsession with independent directors was there to stay, and was in an important sense also aided by courts. In controversies ranging from derivative suits to takeover battles, Delaware jurisprudence increasingly blessed decisions made by independent directors (or special committees thereof) in situations that would otherwise entail a conflict of interest. ${ }^{75}$ This is yet another instance of devolution of decision-making power from the public to the private sector, with independent directors serving as the relevant arbiters of fairness.

\section{The promise of shareholder democracy}

Checks and balances through a monitoring board composed of independent directors was not the only politically inspired remedy to the perceived corporate crisis. Though far less agreeable to business interests, ${ }^{76}$ the application of democracy to the corporate form - especially by increasing shareholder voice and power - was a popular concept among reformists. The corporate governance movement envisioned "a new role" for shareholders in monitoring and disciplining the board. ${ }^{77}$

By the 1980s, the SEC Staff Report on Corporate Accountability acknowledged that "the emerging consensus concerning the proper role of corporate boards of directors, while extremely important, is only one part of the larger effort to enhance

\footnotetext{
${ }^{73}$ See Joel Seligman, A Sheep in Wolf's Clothing: The American Law Institute Principles of Corporate Governance Project 55 GEO. WASH. L. REV. 325 (1987) (“After Ronald Reagan's election in 1980... [b]usiness community opponents of corporate law reform shifted their posture from favoring the most moderate changes to opposing any reform").

74 Letter from Chairman of the Business Roundtable's Corporate Responsibility Task Force to the Business Roundtable, Director's Monthly, Dec. 1982, at 5. For a discussion of the letter, see Victor Brudney, The Role of the Board of Directors: The ALI and Its Critics, 37 U. MIAMI L. REV. 223, 228 (1983) ("In short, the ALI project was no longer a useful foil to the efforts by 'activists' to effect 'reforms.' Since the Business Roundtable's proposals for corporate governance had roots similar to those attributed to the ALI project, perhaps they also are now no longer needed").

${ }^{75}$ Gordon, supra note 13, at 1481 and 1523. See, e.g., Zapata Corp. v. Maldonado, 430 A.2d 779 (Del. 1981); Unocal Corp. v. Mesa Petroleum Co., 493 A.2d 946 (Del. 1985).

${ }^{76}$ At the same time as it supported the shift towards greater board independence, the Business Roundtable was critical of shareholder empowerment. Statement by the Business Roundtable, supra note 59, at 20945 ("We think it appropriate that most of the discussion in the last few years on improvements in the system of corporate governance has focused on the functioning of the board of directors. (...) This focus is undoubtedly based on the widespread appreciation of the practical obstacles to enlarging the role of share owners in the conduct of corporate affairs").

${ }^{77}$ See, e.g., NADER ET AL., supra note 56, at 128-9.
} 
corporate accountability in America," drawing specific attention to the role of shareholders in corporate governance. This was so even though the link between the problems of the time - illegal payments and corporate failures - and the proposed solution of greater shareholder involvement in corporate affairs was tenuous at best. As underlined by the contemporary critique of Daniel Fischel, illegal payments to foreign officials were in fact consistent with the pursuit of shareholders' financial interests. Likewise, attributing financial collapses to a " "breakdown' in corporate accountability" was, in his view, a "colossal nonsequitur" - akin to blaming such corporate failures on the concomitant rise of independent directors during the period. ${ }^{78}$

Yet the view that the lack of shareholder monitoring was at the root of economic underperformance in the United States would only gain force through the growing interest in comparative corporate governance in the 1980 s. $^{79}$ Besides the United Kingdom, a sister jurisdiction, the main focus of comparative investigations were Germany and Japan, the great exemplars of economic success at the time. And, it turned out, Germany and Japan had systems of corporate governance that were markedly different from that of the United States.

Monitoring by large institutional investors - especially financial institutions was a hallmark of German and Japanese corporate governance. The comparative experience underscored that the U.S. system of shareholder apathy was not inevitable, ${ }^{80}$ and might not necessarily be desirable. Combined with the growing awareness about the expansion of institutional ownership in the United States in the 1980s, the German and Japanese experience played a part in inspiring the movement for greater institutional investor activism in the United States.

\section{B. Problem \#2: Promoting Financial and Economic Development}

The corporate governance movement expanded in the 1980s as the product of the particular economic conditions and political context then prevailing in the United States. But it was in the 1990s - described, perhaps prematurely, as the "decade of corporate governance" ${ }^{\text {, }}$ - that the movement went global. In blending a reformist project with a private sector focus, corporate governance would provide an attractive agenda both for international development agencies in charge of promoting economic growth in developing and transitional countries and for think tanks seeking to revitalize the economies of the Wealthy West.

\footnotetext{
${ }^{78}$ Fischel, supra note 12 , at 1267.

${ }^{79}$ This was not the first time in which works on comparative corporate governance made an appearance. In the 1960s, scholars began to suggest that Germany's system of two-tier boards (and codetermination) could serve as an attractive model for the United States. Edward Rock, America's Shifting Fascination with Comparative Corporate Governance, 74 WASH. U. L. Q. 367, 373 (1996).

${ }^{80}$ Louis Lowenstein \& Ira M. Millstein, The American Corporation and the Institutional Investor: Are There Lessons from Abroad? 1988 COLUM. BuS. L. REV. 739, 745 ("in no other major industrial nation is there so deep a chasm between owners and managers”); RoE, supra note 39 (attributing the particular makeup of corporate ownership and governance in the United States to legal constraints enacted as a result of populist politics).

${ }^{81}$ Cheffins, supra note 15, at 59 (quoting a Financial Times column).
} 
A number of factors help explain the increasingly global grip of the corporate governance agenda. First and foremost - and consistent with its U.S. origin - corporate governance reform arose as a substitute for government action in the international context as well. In the 1990s, governments worldwide were in retreat as the fall of the Berlin Wall and the neoliberal ideological sway of the Washington consensus impelled a wave of privatizations and deregulation. In this context, a new system of corporate governance was needed to replace the old one based on state ownership of enterprise. As the early experience with privatizations made painfully clear, the shift to private ownership alone was unlikely to bolster economic performance in the absence of accompanying institutions. ${ }^{82}$

The idea that governance was a substitute for government was explicit in the global embrace of the movement. The influential Principles of Corporate Governance of the Organisation for Economic Co-operation and Development (OECD), first published in 1999, bring home the point. ${ }^{83}$ Their preface is structured around three pillars: (i) it highlights the economic transformation leading to greater reliance on the private sector and market forces in the previous decade; ${ }^{84}$ (ii) it links the rising prominence of corporate governance to the growing "awareness of the importance of private corporations;" ${ }^{85}$ and (iii) it implies that corporate governance - defined as the "internal means by which corporations are operated and controlled" 86 - is not only a product of greater emphasis in the private sector, but also a contributing force to continued private sector dominance. That is, at the same time as the document acknowledges that "governments play a central role in shaping the legal, institutional and regulatory climate within which individual corporate governance systems are developed," it stresses that "the main responsibility lies with the private sector." 87

Second, and relatedly, the reformist ambitions of the corporate governance movement meant that it would gain traction in periods of economic failures or crises. While the initial establishment in 1991 of a U.K. Committee on the Financial Aspects of Corporate Governance, chaired by Sir Adrian Cadbury, drew only limited attention, the "harsh economic climate" and subsequent corporate scandals afflicting British companies Maxwell and BCII soon brought the Committee's efforts into the spotlight. ${ }^{88}$ The work products of the Committee, embodied in the celebrated Cadbury Report and its influential Code of Best Practices, benefited from the attention and sense of urgency spurred by a corporate crisis - a "climate of opinion which accepts that changes are needed," in the words of Sir Adrian Cadbury himself. ${ }^{89}$

${ }^{82}$ Donald J. Johnson \& Joanna R. Shelton, Preface at 7, in OECD PrINCIPLES OF CoRPORATE GOVERNANCE, supra note 20.

${ }^{83}$ Id. ("[o]ver the past decade, the world has witnessed a significant transformation in the role of the private sector in economic development and job creation”).

${ }^{84} I d$.

${ }^{85} \mathrm{Id}$.

${ }^{86} I d$.

${ }^{87} \mathrm{Id}$.

${ }^{88}$ Report of the Committee on the Financial Aspects of Corporate Governance (1992) [hereinafter Cadbury Report], Preface at by Adrian Cadbury.

${ }^{89} I d$. 
But even if the corporate scandals in question were reasonably confined, the ambitions of the corporate governance movement as it expanded in the U.K. were far more grandiose. As was the case in the United States, reform proponents underscored the fundamental role played by corporate governance practices in the economy. The Cadbury Report opens by stating that "[t]he country's economy depends on the drive and efficiency of its companies.” It then immediately posits a strong causal relation between the board of directors and the general economic performance of the country (" $[\mathrm{t}]$ hus, the effectiveness with which their boards discharge their responsibilities determines Britain’s competitive position”). ${ }^{90}$

Even though it was a relative latecomer, Britain's approach to corporate governance, which relied on the promotion of a "Code of Best Practices," would become a particularly successful export in years to come. ${ }^{91}$ To that effect, it was assisted by the progressive reversal of economic fortunes in the 1990s, which prompted a reassessment of the lessons drawn from comparative corporate governance in the prior decade. As the U.S. and U.K. economies took off during this period, the prevailing conceptions about the efficiency of different systems of corporate governance changed accordingly. While in the 1980s the systems of Germany and Japan served as a source of inspiration, in the 1990s the conventional wisdom came to regard the U.S. and U.K. systems as the ultimate models of good corporate governance for both European and developing countries. ${ }^{92}$

A new wave of academic research would soon reinforce this trend. Inaugurated in the 1990s, the booming economic literature on "law and finance," contributed to the increasing prominence of corporate governance reform as an integral part of the recipe for economic development. A growing number of works pointed to the existence of a causal relationship between financial development and economic development. ${ }^{93}$ And a related, though more controversial, literature came to suggest that the level of legal investor protection in a given jurisdiction - as determined by its legal origin (whether common law, or French, German or Scandinavian civil law) - influenced both the degree of ownership dispersion and the observed levels of capital market development. $^{94}$

\footnotetext{
${ }^{90}$ Cadbury Report, Section 1.1.

${ }^{91}$ Brian Cheffins, Corporate Governance Reform: Britain as the Exporter, in 8 HUME PAPERS ON PUBLIC POLICY: CORPORATE GOVERNANCE AND THE REFORM OF THE COMPANY LAW 1 (2000), http://ssrn.com/abstract=215950 (describing the international diffusion of the U.K. approach to corporate governance). But see Cally Jordan, The Conundrum of Corporate Governance, 30 BROOK. J. INT'L L. 983 (2005) (casting doubt on the effectiveness of transplanting Britain's voluntary approach to other contexts).

${ }^{92}$ Rock, supra note 79, at 380-81 ("[t]he tone of comparative scholarship has changed over the last few years as the U.S. economy has bounced back and Germany and Japan have lagged”).

${ }_{93}$ See, e.g., Robert G. King \& Ross Levine, Finance and Growth: Schumpeter Might Be Right, 108 QUART. J. Econ. 717 (1993); Ross Levine \& Sara Zervos, Stock Markets, Banks, and Economic Growth, 88 Am. ECON. REv. 537 (1998); Raghuram G. Rajan \& Luigi Zingales, Financial Dependence and Growth, 88 AM. ECON. REV. 559 (1998).

${ }^{94}$ For a review of this extensive literature by its principal proponents, see Rafael La Porta, Florencio Lopez-de-Silanes \& Andrei Shleifer, The Economic Consequences of Legal Origins, 46 J. EcON. LIT. 285
} 
Taken at face value, one could be tempted to conclude that a logical policy corollary of the law-and-finance literature would be the prescription of sweeping regulatory reforms and a greater role for state intervention. Dispelling such doubts, however, subsequent work suggested that disclosure mandates and private enforcement were superior to public enforcement. ${ }^{95}$ And although development agencies formally embraced legislative reform, a combination of free market ideology and political resistance to legal change by incumbents ${ }^{96}$ redirected the reform efforts to voluntary programs through the private sector.

International development agencies not only supported the creation of stock exchange listing segments requiring greater investor protection - as in Brazil's successful experiment with the Novo Mercado ${ }^{97}$ - but also backed a number of firmlevel corporate governance initiatives. ${ }^{98}$ The World Bank has also sponsored a number of country-specific Corporate Governance Reports on the Observance of Standards and Codes (ROSCs), so as to not only "strengthen regulators," but also to "develop CG codes, and create institutes of directors." 99 International development agencies have thus been instrumental in propagating the view that good corporate governance - as primarily implemented by the private sector - plays a fundamental role in economic development. ${ }^{100}$

Finally, the use of corporate governance to deflect more intrusive modes of state regulation carried forward to the international arena as well. The Cadbury Report was unequivocal in this regard, taking pride in "striking the right balance between meeting the standards of corporate governance now expected of them and retaining the essential spirit of enterprise." ${ }^{101}$ It also explicitly warned that "if companies do not back our recommendations, it is probable that legislation and external regulation will be sought

(2008).

${ }_{95}$ Rafael La Porta, Florencio Lopez-de-Silanes \& Andrei Shleifer, What Works in Securities Laws?, 61 J. FIN. 1 (2006).

${ }^{96}$ For an account of the opposition by existing elites to corporate governance change in Brazil, see Ronald J. Gilson, Henry Hansmann \& Mariana Pargendler, Regulatory Dualism as a Development Strategy: Corporate Reform in Brazil, the United States, and the European Union, 63 STAN. L. REV. 475 (2011).

${ }^{97}$ See id. (explaining how the voluntary character of the Novo Mercado's standards served to appease political resistance to legal reforms); 5 FocUS: NOVO MERCADO AND ITS FOLLOWERS (2008) (for a description of the process leading to the creation of the Novo Mercado).

${ }^{98}$ An instance of this approach is the IFC-sponsored Latin American Companies Circle, an initiative which "brings together a group of leading Latin American companies who have adopted good corporate governance practices in order to provide private sector input into the work of corporate governance regional development and to share their experiences with each other and other companies in the region and beyond"). See www.ifc.org.

99 The World Bank \& IFC, Improving Corporate Governance in Emerging Markets, http://siteresources.worldbank.org/FINANCIALSECTOR/Resources/Corporate_Governance_Introductio n.pdf.

${ }^{100}$ For an articulation of the channels contributing to this link, see Stijn Claessens, Corporate Governance and Development, 1 Focus 1 (2003); Claessens \& Yurtoglu, supra 1.

${ }^{101}$ Cadbury Report, supra note 88 (item 1.5). 
to deal with some of the underlying problems which the report identifies.”102

All in all, the internationalization of corporate governance also served as a substitute for government action in two mutually reinforcing ways. The increasing retreat of the state propelled the decision-making processes of private corporations further into the spotlight. ${ }^{103}$ At the same time, the advancement of the corporate governance agenda reinforced this trend by crowding out attempts at greater governmental intervention.

\section{Problem \#3: Corporate Fraud}

As the "corporate governance decade" drew to a close with the successful export of the Anglo-Saxon blueprint, the emergence of high-profile corporate scandals in the early 2000s in the United States reignited the debate. The unveiling of massive financial fraud at U.S. giant energy firm Enron was followed by similar problems at WorldCom, Tyco, and Adelphia. These failures were striking for at least three reasons.

First, they took place at the United States, which at the time enjoyed the status of international paragon of good corporate governance. ${ }^{104}$ Second, Enron itself had formally exemplary corporate governance practices: its highly independent board was composed of directors with stellar credentials, boasted a sophisticated committee structure, and met frequently. ${ }^{105}$ Third, prior progress in the corporate governance movement in encouraging managers to maximize share prices might have, inadvertently, created the very incentives for doing so at any cost - even if by fraudulent means. ${ }^{106}$

The sheer magnitude of the Enron debacle - which, among other things, wiped

${ }^{102}$ Id. (item 1.10).

${ }^{103}$ See, e.g., Claessens \& Yurtoglu, supra note 1, at 1 ("The private, market-based investment process is now much more important for most economies than it used to be; that process needs to be underpinned by better corporate governance”).

${ }^{104}$ Gilson, supra note 14, at 143 ("By the close of the 1990s, the United States corporate governance system... was treated as the end point in the burgeoning convergence literature and was the template for the reform efforts of major NGOs, like the World Bank, the OECD and the International Monetary Fund”); Jonathan R. Macey, Efficient Capital Markets, Corporate Disclosure, and Enron, 89 CoRNELL L. REV. 394, 395 (2004) (describing how the Enron scandal challenged the prevailing belief that "the U.S. corporate governance system is the best in the world").

105 Troy A. Paredes, Enron: The Board, Corporate Governance, and Some Thoughts on the Role of Congress, in ENRON: CORPORATE FIASCOS AND THEIR IMPLICATIONS 495, 504-5 (Nancy Rapoport \& Bala Dharan eds., 2004) (noting that "by all appearances the Enron board looked great," as its directors "reflected a wide range of business, finance, accounting, and government experience," the board exhibited "all the committees one would hope to see," and its audit committee "had a model charter and was chaired by a former accounting professor who had served as the Dean of the Stanford Graduate School of Business"); MACEY, supra note 12, at 80 (observing that the "Enron board was widely lauded as a shining example of good corporate governance," with all members of compensation, nomination and audit committees being unaffiliated with management").

${ }^{106}$ John C. Coffee, Jr., What Caused Enron - A Capsule Social and Economic History of the 1990s, 89 CORNELL L. REV. 269 (2003-2004) (attributing the scandals, inter alia, to the rise of equity-based compensation schemes (such as stock options) in the United States, prompted by the greater role of institutional investors). 
out US\$ 60 billion in market capitalization and US\$ 2 billion in pension plans ${ }^{107}$ triggered public calls for reform. This was so even though the fraudulent conduct in question was already considered criminal under existing law. Indeed, Enron's executives endured extraordinarily long jail sentences as a result of their actions. Enron CEO Jeffrey Skilling was sentenced for 24 years (subsequently reduced to 14), CFO Andrew Fastow received a six-year sentence after cooperating with the prosecution, and former board chair and CEO Kenneth Lay faced dozens of years in prison when he died prior to his sentence in $2006 .^{108}$

The legislative response to the Enron scandal came in the form of the SarbanesOxley Act of 2002 ("SOX"), described by then President George W. Bush as "the most far reaching reforms of American business practices since the time of Franklin Delano Roosevelt."109 In SOX, the compromise character of the corporate governance solution offered an attractive blueprint for policymakers. If SOX innovated in imposing federal corporate governance mandates for the first time in U.S. history, ${ }^{110}$ it followed the new tradition of treating internal checks and balances within the corporation (and other private sector gatekeepers as well) as a universal remedy.

Although SOX contained its fair share of traditional regulatory mandates (ranging from new financial disclosures to insider trading prohibitions and criminal sanctions), it also reflected and reinforced the growing corporate governance obsession. Instead of solely compelling or proscribing specific conducts or increasing existing sanctions, it also placed greater weight on the ability of private sector actors to act as monitors and arbiters. Two of the most salient statutory additions - the requirement of wholly independent audit committees and the mandate of executive certification of financial statements - fall squarely within the concept of a corporate governance solution. In the same spirit, a number of other rules relied on other types of private gatekeepers, such as auditors, attorneys, analysts, and whistleblowers.

The apparent contradiction in imposing further corporate governance prescriptions in response to Enron did not escape observers - but did little to derail the initiative. Particularly striking was the disjunction between the causes of the collapse and the new statutory requirements. As noted by Jonathan Macey, it is ironic that "Enron itself already met or exceeded the standards ostensibly promulgated to prevent future 'Enrons.",111

Roberta Romano advanced an influential critique of the substantive mandates

\footnotetext{
10710 Years Later: What Happened To The Former Employees Of Enron?, BusINESS INSIDER, Dec. 1, 2011.

${ }^{108}$ Richard Partington, The Enron Cast: Where Are They Now?, Fin. NEWs, Dec. 1, 2011.

109 President George W. Bush, Statement on Signing the Sarbanes-Oxley Act of 2002, July 30, 2002, http://www.presidency.ucsb.edu/ws/?pid=64514.

${ }^{110}$ Romano, supra note 18, at 1523.

${ }^{111}$ MACEY, supra note 12, at 81 (Enron "would not need to change its corporate governance structure at all to conform to the requirements of the Sarbanes-Oxley Act); Romano, supra note 18 (arguing that the "ostensible remedies for future 'Enrons' reforms that had minimal or absolutely no relation to the source of that firm's demise”).
} 
embraced by SOX. ${ }^{112}$ She described the reform as a set of "recycled ideas advocated for quite some time by corporate governance entrepreneurs" whose effectiveness was either unconfirmed or positively denied by the existing empirical evidence. ${ }^{113}$ Romano attributes what she regarded as the flawed legislative outcomes in SOX to the "frantic political environment." 114

Even if puzzling at first sight, the lack of empirical support to the efficacy of the corporate governance practices mandated by SOX is perfectly consistent with the compromise character of the corporate governance obsession. For one, empirical ambiguity facilitates bipartisan support. Moreover, even reforms that are ultimately ineffectual can be useful in fending off more intrusive modes of government intervention. ${ }^{115}$ This is a plausible reason why SOX was initially able to garner support even from conservative associations, such as the Business Roundtable, ${ }^{116}$ which later reversed its stance on the statute once the threat of regulation was gone. ${ }^{117}$

Moreover, to the extent that SOX also encompassed new regulatory requirements, it would soon come under attack based on the argument that the associated compliance costs decreased the competitiveness of U.S. capital markets. Interestingly, the reaction against regulation once again took the form of a corporate governance solution - this time through an emphasis on shareholder empowerment. The influential report of the Committee on Capital Markets Regulation advocated for stronger shareholder rights which, in its view, "go hand in hand with reduced regulation or litigation."118

\section{Problem \#4: Financial Crisis of 2008}

A few years after Enron, the financial crisis of 2008 and its devastating economic consequences raised another serious problem in search of a solution. The emerging analyses of the crisis’ root causes - whether a market failure or a government failure - split along predictable lines. On the one hand, a growing number of scholars (including conservative converts) attributed the financial crisis to the wave of financial deregulation in the previous decades, which eliminated existing constraints to the operation of banks and the trading of derivatives. ${ }^{119}$ On the other hand, a number of

\footnotetext{
112 Romano, supra note 18.

113 Id. at 1523.

${ }^{114}$ Id. at 1523.

${ }^{115}$ For a similar argument in the context of mutual fund governance, see John Morley \& Quinn Curtis, Taking Exit Rights Seriously: Why Governance and Fee Litigation Don't Work in Mutual Funds, 120 YALE L.J. 84, 140-2 (2010).

${ }^{116}$ Romano, supra note 18, at 1564 (describing how the business community split over the bill, with the Business Roundtable supporting and the Chamber of Commerce opposing its enactment). Romano interprets the Business Roundtable's support to the bill as being motivated by large firms' desires to dissociate themselves from Enron. Id. at 1565.

${ }^{117}$ Hillary A. Sale, The New "Public" Corporation, 74 LAW \& CONTEMP. PROBS. 137, 148 (2011).

${ }^{118}$ INTERIM REPORT OF THE COMM. ON CAPITAL MKTS 16 (2006).

119 As examples of studies in this large literature, see Patricia A. McCoy, Andrey D. Pavlov \& Susan M. Wachter, Systemic Risk through Securitization: The Result of Deregulation and Regulatory Failure, 41 CONN. L. REV. 493 (2009); RICHARD POSNER, A FAIluRE OF CAPITALISM: ThE CRISIS OF '08 AND THE DesCEnT Into Depression (2011); Lynn A. Stout, Derivatives and the Legal Origin of the 2008 Credit
} 
commentators ascribed the financial collapse to misguided government policies, which, among other things, fueled the subprime mortgage market through implicit subsidies and guarantees. ${ }^{120}$

Yet for both ends of the ideological spectrum corporate governance would play a major role - both as the identified culprit for the crisis and as a recipe for reform. The financial crisis was linked to corporate governance failures in numerous - and at times conflicting - ways. A prominent argument was that the financial crisis was, in an important sense, a variation of the incentives problem that first became apparent in the Enron affair. In the words of Treasury Secretary Tim Geithner, "[t]his financial crisis had many significant causes, but executive compensation practices were a contributing factor." 121 The argument was that, once again, performance-based executive compensation had induced executives to misbehave - if not by engaging in outright fraud (as was the case in the scandals of the early 2000s), at least by undertaking excessive risk to increase short-term gains to the detriment of the firm's long-term performance. $^{122}$

A related concern was that stock options - in the past hailed as the ultimate instrument for linking pay to performance - could generate perverse incentives if markets are less than perfectly efficient. Stock options create incentives for risk-taking, for they only benefit managers if share prices increase within the exercise period. Yet such an asymmetric scheme (which rewards the upside but fails to punish any downside) fails to align managerial incentives with those of shareholders, whose wealth is affected by both upward and downward stock price movements. ${ }^{123}$

A competing account offered a different diagnosis, suggesting that the existing corporate governance structures in fact made the governance of financial institutions more aligned with the interests of shareholders than would otherwise be optimal. ${ }^{124}$ The reason behind this view is the recognition that - in light of systemic risk and the negative externalities generated by the failure of a large financial institution - the pursuit of shareholder wealth maximization fails to promote social welfare. The

Crisis, 1 HARV. Bus. L. REV. 1 (2011).

120 See, e.g., Peter J. Wallison, Cause and Effect: Government Policies and the Financial Crisis, AEI Online, Nov. 25, 2008; John A. Allison, The Financial Crisis and the Bank Deregulation Myth, FoRBES, Dec. 10, 2012; RAGHURAM G. RAJAN, FAULT LiNES (2010) (interpreting the government's promotion of credit and consumption as an attempt to counterbalance growing inequality).

121 Tim Geithner, Treasury Secretary, Statement on Compensation (June 10, 2009), http://www.treasury.gov/Press-center/Press-releases/Pages/tg163.aspx (adding that “[i]ncentives for short-term gains overwhelmed the checks and balances meant to mitigate against the risk of excess leverage”).

${ }^{122}$ Lucian A. Bebchuk, Alma Cohen \& Holger Spamann, The Wages of Failure, 27 YALE J. REG. 257, 261 (2010) (concluding that "given the structure of executives' payoffs, the possibility that risk-taking decisions were influenced by incentives should not be dismissed, but rather, should be taken seriously”).

123 See, e.g., William T. AlLEN, REINIER KRAAKMAN, GUHAN SUBRAMANIAN, COMMENTARIES AND CASES ON THE LAW OF Business ORGANIZATION (4th ed., 2012) (describing the view that, given the predominance of stock-option pay, "the highly leveraged investments that seemed excessively risky in hindsight were the inevitable consequences of sophisticated managers responding rationally to their compensation system”).

${ }^{124}$ See, e.g., Lucian A. Bebchuk \& Holger Spamann, Regulating Bankers’ Pay, 98 GEO. L.J. 247 (2010). 
argument was forcefully illustrated by the billions of dollars of public money spent in rescuing the financial sector and by the deleterious economic consequences of the financial crisis in terms of growth and unemployment.

Beyond the realm of executive compensation, the financial crisis was linked to corporate governance failures of different stripes. First and foremost, boards of directors received the blame. Specifically, the lack of effective oversight of risk management by corporate boards was a recurrent object of criticism. ${ }^{125}$ Corporate governance reports pointed out that failing financial institutions fell short of corporate governance best practices, such as the split in the positions of board chair and CEO. ${ }^{126}$ Other accounts called into question the role of institutional investors (or lack thereof) in monitoring firm risk and performance. ${ }^{127}$

Similarly to what transpired in the enactment of SOX in response to the Enron collapse in the early 2000s, corporate governance again played a conspicuous role in the legislative response to the financial crisis embodied in the Dodd-Frank Act of 2010. The corporate governance obsession resulted, once again, in a variety of new rules that bore little direct relationship to the causes of the financial collapse. Although the provisions were numerous, the resulting corporate governance mishmash was largely symbolic; effective changes in the ultimate balance of power within the corporation were incremental at best.

The main additions to the corporate governance soup followed the traditional recipe of enhancing board independence and increasing shareholder power. With respect to the former, the focus this time around was on members of the compensation committee, which are now required to meet independence standards similar (but not identical) to those imposed on audit committee members by SOX. The new independence requirements also extend to any advisors engaged by the compensation committee, such as legal counsel and compensation consultants. Furthermore, although companies retained flexibility in choosing their board leadership structure, Dodd-Frank requires them to explain the reasons why they chose to combine or to split the roles of board chair and CEO.

The recurring focus on board structure again reflected the attempt to replace outside constraints with internal checks. As expressed at the time by Harvard fellow and former GE executive Ben Heinemann, "the board of directors stands between government regulation and corporate freedom... When boards don't succeed but fail, the terms of the debate shift from how best companies can govern themselves to how regulators should govern them." 128

In addition to enhancing board independence, the corporate governance

\footnotetext{
${ }^{125}$ See, e.g., OECD, CORPORATE GOVERnANCE AND THE FinANCIAL CRISIS: Key Findings AND MAIN MESSAGES 8 (2009) ("Most important of all, boards were in a number of cases ignorant of the risk facing the company").

${ }^{126}$ Millstein Ctr. for Corp. Governance \& Performance, supra note 64, at 18.

127 See, e.g., Corporate Governance FaIlures: The Role of Institutional InVESTORS in the GlobAl FinANCIAL CRISIS (James P. Hawley, Shyam J. Kamath \& Andrew T. Williams eds., 2011).

${ }^{128}$ Ben W. Heineman, Jr., Boards Fail - Again, BusinEssWeEK, Sept. 26, 2008.
} 
obsession led Dodd-Frank to include a number of provisions devised to enhance shareholder participation in corporate governance. The main novelty in that respect was the introduction of a "say on pay" mandate - the requirement that companies periodically give shareholders the opportunity to cast an advisory (i.e., nonbinding) vote on executive compensation. This regime, which had been in force in the U.K. since 2002, was a favorite among U.S. institutional investors. ${ }^{129}$ The Senate Committee justified the rule based on the revelations following the financial crisis of exorbitant pay packages in the face of poor company performance. ${ }^{130}$

Dodd-Frank also strengthened the role - if not necessarily the power ${ }^{131}$ - of shareholders in various ways. The statute prohibited broker discretionary voting in director elections and other significant matters. Because broker votes were famously cast in favor of management, the measure effectively increased the clout of institutional investors. In the same spirit, Dodd-Frank explicitly authorized (but did not require) the SEC to issue regulations granting proxy access to shareholders for director nominations. $^{132}$

Already visible in SOX, the ever-increasing emphasis on governance in lieu of regulation was conspicuous in Dodd-Frank as well. The shift from regulatory to governance solutions is particularly clear in the area of executive compensation. In the 1990s, the political reaction to high CEO pay came in the form of a clear rule: specifically, the addition of Section 162(m) to the Internal Revenue Code, which limits the deductibility of executive compensation to US\$1 million unless it was substantially based on performance. ${ }^{133}$ By the 2000s, however, this strategy had been discredited not least because it arguably had the unintended consequence of significantly increasing the overall pay levels without a commensurate sensitivity to performance. ${ }^{134}$ Instead of imposing public constraints on private action, SOX and Dodd-Frank at most tweaked the internal balance of power and incentive structure within the corporation to

${ }^{129}$ For an analysis of the origins and the international expansion of "say on pay" legislation, see Randall S. Thomas \& Christoph Van der Elst, The International Scope of Say on Pay (ECGI Law Working Paper No. 227, 2013), http://ssrn.com/abstract=2307510.

${ }^{130}$ S. REP. 111-176 (The Committee on Banking, Housing, and Urban Affairs): The Restoring American Financial Stability Act of 2010.

${ }^{131}$ See George S. Georgiev, Shareholder vs. Investor Primacy in Federal Corporate Governance, 62 UCLA L. REV. DisC. 71, 72 (2014) (arguing that Dodd-Frank, by itself, has not accorded any unique and meaningful governance rights to shareholders as a group).

${ }^{132}$ The import of such a provision was largely symbolic, however, since it was widely believed that the SEC already had such authority under existing legislation. Stephen M. Bainbridge, Dodd-Frank: Quack Federal Corporate Governance Round II, 95 MinN L. REV. 1779, 1802 (2011). In any event, the DC Circuit invalidated the proxy access rules promulgated by the SEC in 2010 as an arbitrary and capricious exercise of agency power, criticizing the cost-benefit analysis conducted by the agency. Business Roundtable v. SEC, 647 F.3d 1144 (D.C. Cir. 2011).

${ }^{133}$ Internal Revenue Code of 1986, Section 162(m). Even this rule, however, had a clear governance component, since the deductibility of performance-based compensation was conditioned on the determination of performance goals by a committee composed exclusively of outside directors.

${ }^{134}$ Gregg D. Polsky, Controlling Executive Compensation through the Tax Code, 64 WASH. \& LEE L. REv. 877 (2007) (for a review of the empirical literature). But see Nancy L. Rose \& Catherine Wolfram, Regulating Executive Pay: Using the Tax Code to Influence Chief Executive Officer Compensation, $20 \mathrm{~J}$. LAB. ECON. 138 (2002) (finding that executive pay decisions were not much influenced by the new tax regime). 
encourage private actors to police themselves. ${ }^{135}$

In an op-ed in the Wall Street Journal entitled "Crazy Compensation and the Crisis," Princeton economist and prior member of the Clinton administration Alan Binder articulates this view:

"It is tempting to conclude that the U.S. (and other) governments should regulate compensation practices to eliminate, or at least greatly reduce, go-for-broke incentives. But the prospects for success in this domain are slim. (I was in the Clinton administration in 1993 when we tried - and failed miserably.) The executives, lawyers and accountants who design compensation systems are imaginative, skilled and definitely not disinterested. Congress and government bureaucrats won't beat them at this game. Rather, fixing compensation should be the responsibility of corporate boards of directors and, in particular, of their compensation committees."136

\section{E. Problem \#5: Inequality and Other Social Issues}

Finally, as a return of sorts to its roots, corporate governance has recently been enlisted as a solution to the great social issues of our time, such as income inequality, gender imbalance, human rights, and environmental protection. In this respect, the corporation and its governance not only substitute for state action, but also become the focal point in which a number of social problems are exposed and supposedly addressed.

\section{(i) Rising inequality}

The concern about growing inequality - described by President Obama as the "defining challenge of our time" 137 - epitomizes this trend. First, the most widely cited figures to demonstrate the degree of rising inequality in the United States concern the growing gap between the wage of the average worker and that of public company CEOs. The ratio between the pay of U.S. CEOs and that of the average production worker increased from 20 times in 1965 to 231 times in 2011, after peaking at 383.4 times in $2000 .{ }^{138}$ The fact that other occupations - from lawyers and athletes to private

\footnotetext{
${ }^{135}$ Building on the trend that began with SOX, Dodd-Frank strengthened the requirement of clawbacks of executive compensation that turns out to have been based on materially inaccurate financial information. To be sure, clawbacks are not a pure governance solution, insofar as the state has imposed substantive constraints on corporate policy. Still, the clawback mandate has an important governance component. Rather than specifying the nuts and bolts of the clawback mechanics, it requires companies to do so themselves in their own clawback policies. In doing so, it devolves policymaking authority to the private sector and relies on the operation of the firms' internal checks and balances (such as shareholder votes and proxy advisors) to make sure that the regime ultimately adopted is a sensible one.

${ }^{136}$ Alan S. Binder, Crazy Compensation and the Crisis, WALL ST. J., May 28, 2009.

137 President Barack Obama, Remarks by the President on Economic Mobility (Dec. 4, 2013), http://www.whitehouse.gov/the-press-office/2013/12/04/remarks-president-economic-mobility.

${ }^{138}$ Economic Policy Institute, CEO Pay and the Top 1\%: How Executive Compensation and FinancialSector Pay Have Fueled Income Inequality, ISSUE BRIEF 331, May 2, 2012. For an alternative measurement that drew significant attention, see Paul Krugman, For Riches, N.Y. Times, Oct. 20, 2002 (noting that while the annual compensation of the top 100 CEOs was on average 39 greater than that of
} 
equity and hedge fund managers - experienced similar gains to those of CEOs during the same period has received far less attention in the public debate. ${ }^{139}$

Yet corporate governance emerged not only as the focal point of the debate about rising inequality but also as a likely contributor to the problem. Although scholars have identified a number of factors to explain the soaring levels of income inequality, corporate governance failure appears as a recurrent culprit. For Nobel laureate Paul Krugman, the "monumental executive incomes" are a product not of the "invisible hand of the market," but of the "invisible handshake in the boardroom." "140 Joseph Stiglitz, another Nobel laureate in economics, had declared that "weak corporate governance and eroding social cohesion have led to increasing gaps between the pay of chief executives and that of ordinary worker."141

As an illustration of how mainstream the link between corporate governance and inequality has become, the Wikipedia entry on "Income Inequality in the United States" specifically refers to corporate governance as a possible explanatory variable. ${ }^{142}$ Corporate governance has also made it to Thomas Piketty's celebrated opus "Capital in the Twenty-First Century,” where he argues that "extremely high executive pay” offers "the most convincing proof of the failure of corporate governance." ${ }^{143}$ Yet Piketty, who has shown little concern for offering politically viable responses to growing inequality, is skeptical about the promise of corporate governance change to remedy the problem. $^{144}$

Nonetheless, the mainstream position is that corporate governance reform can help tackle inequality, too. In his recent book devoted to the negative implications of growing inequality, Stiglitz not only identifies corporate governance failure as a cause of the problem, but also corroborates the corporate governance obsession by advocating for "improving corporate governance" - by curbing executive power, implementing a "say on pay," and enhancing disclosure - as an effective solution. ${ }^{145}$

In this light, the new requirements with respect to compensation committee independence and the adoption of "say on pay" by Dodd-Frank can also be interpreted

the average worker in 1970, the difference had soared to 1,000 times more by 1999).

139 For a description of comparable increases in the levels of compensation in other occupations, see Steven N. Kaplan, Executive Compensation and Corporate Governance in the U.S.: Perceptions, Facts and Challenges, 25 J. ApPLIED CORP. FIN. 8 (2013).

${ }^{140}$ Krugman, supra note 138.

141 Joseph E. Stiglitz, Inequality Is a Choice, N.Y. TIMES, Oct. 13, 2013.

142 See http://en.wikipedia.org/wiki/Income_inequality_in_the_United_States (last visited on Sept. 3, 2014).

143 ThOMAs PiketTy, CAPITAL IN THE TWENTY-FIRST CENTURY 346 (2014).

${ }^{144} \mathrm{Id}$. at 512 ("the idea that skyrocketing executive pay is due to lack of competition, and that more competitive markets and better corporate governance and control would put an end to it, seems unrealistic”).

145 Joseph Stiglitz, The PRICE OF INEQUALITY 271 (2012) ("Improving corporate governance especially to limit the power of the CEOs to divert so much of corporate resources for their own benefit. Too much power, too much deference to their supposed wisdom, is given to corporate executives. We have seen how they use that power to divert too much of the corporation's resources to their own benefit. Laws that give shareholders a say on pay would make a difference. So would accounting rules that let shareholders know clearly how much they're giving away to their executives”). 
as a universal remedy that tackles inequality as well - a problem that is broader, and distinct from, shareholder value and systemic risk. The concern with pay equity and growing inequality is particularly clear with respect to say on pay. House Report 11088, issued in connection with the earlier bill on say on pay, noted that "in 1991, the average large-company CEO received approximately 140 times the pay of an average worker; in 2003, the ratio was about 500 to $1 .{ }^{\text {,146 }}$

The desire to address inequality through corporate governance is particularly clear in the novel - and highly controversial - disclosure requirement, also introduced by Dodd-Frank, about the gap between the compensation of the company's CEO and the median pay of all company employees. ${ }^{147}$ Although some commentators have argued that such disclosure is addressed to society more generally, there is presumably also hope that shareholders may provide a check for companies whose pay ratios they disapprove from a financial or moral perspective. ${ }^{148}$

\section{(ii) Gender inequity}

Another related area in which corporate governance became the focal point of social debate is that of gender inequality. The available data has suggested that the growth in gender participation and equality in the workforce has stagnated or recoiled in recent years. Interestingly, the proportion of women in boardrooms has assumed special salience in that debate. A widely cited statistic is that, even though women comprise a majority of college graduates, they occupy a small fraction of the board seats in publicly traded companies. ${ }^{149}$ As of 2012, women accounted for only $16.6 \%$ of directors of Fortune 500 boards. ${ }^{150}$

Consistent with the pattern observed in other areas, corporate governance change appeared as solution to gender inequality as well. While some countries sought to address gender imbalances by creating quotas for political representation, ${ }^{151}$ many others have done so also or exclusively at the boardroom level. Beginning with the introduction of the pioneering 40\% quota for female directors in Norway in 2006, gender quotas in the boardroom have since spread to several other countries, such as Belgium, France, Italy, and the Netherlands. ${ }^{152}$ A number of other jurisdictions -

\footnotetext{
${ }^{146}$ Bainbridge, supra note 132, at 1808 and H.R. REP. No. 110-88, at 3 (2007).

147 An alternative interpretation is that the pay-ratio rule serves union interests in obtaining leverage for purposes of collective bargaining. The rule was introduced by Democrat Senator John Menendez, who has strong ties to unions, in exchange for his vote in support of the bill. Jerry Markon \& Dina ElBoghdady, Pay Rule Still Unwritten amid Corporate Push, WASH. PosT, Jul. 6, 2013, at A1.

${ }^{148}$ Michael Hiltzik, CEO-to-Worker Pay Gap Is Obscene; Want to Know How Obscene?, L.A. TIMES, Oct. 20, 2013 ("Unlike most SEC regulations, the CEO rule isn't really designed to provide information for investors. Rather, it's designed to provide information for the larger community — for society, if you will").

149 The Economist Explains, The Spread of Gender Quotas for Company Boards, Mar. 25, 2014, http://www.economist.com/blogs/economist-explains/2014/03/economist-explains-14.

${ }^{150}$ Anne L. Alstott, Gender Quotas for Corporate Boards: Options for Legal Design in the United States, 26 PACE INT’L L. REV. 38, 38 (2014).

151 For a list of such countries, see World Economic Forum, Global Gender Gap Report 2013, http://www.weforum.org/reports/global-gender-gap-report-2013.

${ }^{152}$ Alstott, supra note 150 , at 39.
} 
including Denmark, Germany, and Spain - have voluntary systems in place. ${ }^{153}$

The United States has so far refrained from mandating a quota system, which at first glance may appear incompatible with its legal culture and ideology. ${ }^{154}$ Even so, corporate governance has still been called to address the issue of gender balance. The California Senate, for instance, has urged California public companies to have one to three female directors by the end of 2016. ${ }^{155}$ More generally, the SEC amended its proxy rules in 2009 so as to require disclosure of the company's policy with respect to diversity in the director nomination process. ${ }^{156}$

\section{(iii) Human rights and the environment}

Finally, corporate governance has also been harnessed to address other social issues, such as human rights and environmental protection. In this spirit, a number of recent initiatives stand out. Among its various provisions, the Dodd-Frank Act requires companies to disclose the use of conflict minerals from the Democratic Republic of the Congo, a measure designed to address the humanitarian crisis in the region. ${ }^{157}$ In 2014 , the European Parliament enacted a new directive requiring the disclosure of nonfinancial information in management reports, such as "policies, risks and outcomes as regards environmental matters, social and employee-related aspects, respect for human rights, anti-corruption and bribery issues, and diversity in their board of directors.”"158

These initiatives embody the elements of the corporate governance obsession. The notion that corporations should strive to respect human rights and protect the environment in ways that go above and beyond the legal requirements is premised on the economic significance of corporations and the comparative powerlessness of government. The advantage of also addressing the issue through corporate (rather than government) action may be due to the inherent fallibility of regulation in implementing optimal legal sanctions, ${ }^{159}$ to the greater expediency of private sector action in promoting change, ${ }^{160}$ or to the public governance void in the international context. ${ }^{161}$

\footnotetext{
153 Id.

${ }^{154} \mathrm{Id}$.

155 S. Concurrent Res. 62, July 11, 2013 - Relative to Women on Corporate Boards.

156 Tamara S. Smallman, The Glass Boardroom: The SEC's Role in Cracking the Door Open So Women May Enter, 2013 Colum. Bus. L. REV. 801 (analyzing the proxy statements of Fortune 50 firms and finding significant levels of noncompliance with the new mandates).

157 The D.C. Circuit has held the statute and the rule to be partly unconstitutional as it deemed the requirement to report that a company's products "have not been found to be 'DRC conflict free' a violation of the First Amendment. Nat'l Ass'n of Mfrs. v. SEC, 2014 WL 1408274 (D.C. Cir., Apr. 14, 2014).

${ }^{158}$ European Commission, Non-Financial Reporting, http://ec.europa.eu/internal_market/accounting/nonfinancial_reporting/index_en.htm.

159 Einer Elhauge, Sacrificing Corporate Profits in the Public Interest, 80 N.Y.U. L. REV. 733 (2005) (arguing that efficiency requires legal mandates to be complemented by social and moral sanctions).

160 Milton Friedman, The Social Responsibility of Business is to Increase its Profits, N.Y. TIMES MAGAZINE, Sept. 13, 1970 (articulating and rebutting the view that "the problems are too urgent to wait on the slow course of political processes, that the exercise of social responsibility by businessmen is a quicker and surer way to solve pressing current problems”.

${ }^{161}$ Report of the Special Representative of the Secretary-General on the Issue of Human Rights and
} 
Moreover, the strategy relies on applying to the corporate form the traditional methods of government control, such as democracy and transparency. Shareholders have played an active role in striving to shape corporate policy through the growing use of shareholder proposals - and a central corporate governance debate has revolved around the shareholders' authority to include such proposals (especially when in precatory form) in the firm's proxy statements. ${ }^{162}$ By 2010, social and environmental issues accounted for the lion's share of all shareholder proposals. ${ }^{163}$ The rationale for investor involvement is clearly one of substitution for governance failure. As law firm Fried Frank put it in a memorandum commissioned by Special U.N. Representative on Business and Human Rights, John Ruggie, "[i]n the United States, there are two principal mechanisms for compelling corporate conduct: governmental action (through legislation and judicial enforcement) and shareholder action.”164

Enhanced transparency is another way in which a classic recipe for government accountability has been transposed to the corporate form. Unlike traditional disclosure mandates in securities regulation, the goal of these new requirements is not only to assist investors in making informed buy, sell, and pricing decisions, but also to affect substantive corporate behavior. ${ }^{165}$ The hope is that - once the information is available market forces can complement government regulations in compelling socially responsible behavior. A European Union statement expressly articulates the expectation that "consumers and investors are in a position to enhance market reward for socially responsible companies through the consumption and investment decisions they take." 166

Nevertheless, the extent to which real-world shareholders (and consumers ${ }^{167}$ )

Transnational Corporations and Other Business Enterprises: Protect, Respect and Remedy: A Framework for Business and Human Rights, U.N. Doc. A/HRC/8/5 (Apr. 7, 2008), at 3 [hereinafter Ruggie Report] ("The root cause of the business and human rights predicament today lies in the governance gaps created by globalization - between the scope and impact of economic forces and actors, and the capacity of societies to manage their adverse consequences").

${ }^{162}$ For a discussion, see Fried Frank LLP, Trends in the Use of Corporate Law and Shareholder Activism to Increase Corporate Responsibility and Accountability for Human Rights, Dec. 2007, at 1-2, http://www.business-humanrights.org/Links/Repository/846297 [hereinafter Fried Frank Memo].

${ }^{163}$ Ernst \& Young, Shareholders Press Boards on Social and Environmental Risks, at 1 (2011).

${ }^{164}$ Fried Frank Memo, supra note 162, at 1.

165 Bainbridge, supra note 132, at 1797 (describing such "therapeutic disclosures" as designed not to "inform investors," but rather to "affect substantive corporate behavior"). See also Troy A. Paredes, Blinded by the Light: Information Overload and Its Consequences for Securities Regulation, 81 WASH. U. L. Q. 417 (2003) ("The strategy of shaming is premised on actively using disclosure to influence corporate conduct”).

166 European Comm'n, A Renewed EU Strategy 2011-14 for Corporate Social Responsibility, Oct. 25, 2011, at 7.

${ }^{167}$ Encouragingly, both survey results and recent experimental evidence suggests that at least some consumers might be willing to pay more for socially-responsible products. See, e.g., Jens Hainmueller \& Michael J. Hiscox, The Socially Conscious Consumer? Field Experimental Tests of Consumer Support for Fair Labor Standards (Working Paper, 2012) (finding that labels with information about fair labor standards increased sales of more expensive women's items by $14 \%$, but had no impact on the sales of lower-priced items), http://ssrn.com/abstract=2062435; Jens Hainmueller \& Michael J. Hiscox, Buying Green? Field Experimental Tests of Consumer Support for Environmentalism (Working Paper, 2012), 
can fulfill such a function remains an open question. As Edward Rock put it, policymakers may be looking for "a very different sort of shareholder, more like a rich uncle who, while demanding, is ultimately focused on doing what is best for the family as a whole, one who 'can be encouraged to take an interest in sustainable returns and longer term performance' even at the cost of lower returns." 168 It is therefore critical to assess whether corporate governance is able to deliver on such growing expectations, an issue to which we now turn.

\section{The Merits of the Corporate Governance Obsession}

While the normative properties of individual corporate governance practices are the object of an immense literature, the merits of this growing obsession with corporate governance as a whole have received little scrutiny. The recent work by Marcel Kahan and Edward Rock, which undertakes to examine the gap between rhetoric and reality in corporate politics, is a notable exception. After analyzing a number of high-profile corporate governance controversies, the authors find that the actual "stakes hardly seem to justify the intensity of the contest." 169 The explanation for these empty controversies, they conclude, lies in their symbolic or folkloristic character. ${ }^{170}$

Given the prominence of the corporate governance agenda in the academic and public spheres - and its resilience despite variations in the specific issues of the day -, further appraisals of its normative implications are badly needed. There are two competing normative justifications for the corporate governance obsession: while the first view is based on the relationship between corporate governance and shareholder value, the second conception assumes a direct effect of corporate governance on nonshareholder constituencies and social welfare more generally. ${ }^{171}$ Although a definitive normative assessment of the corporate governance obsession is outside the scope of this Article, the following discussion traces the distinct dimensions that should be addressed before concluding whether such game is worth the candle. Specifically, to the extent that corporate governance crowds out other modes of state intervention in the policy space, its benefits need to be traded off not only against its costs, but also against its alternatives.

\section{(i) The shareholder value channel}

The most popular normative defense of the corporate governance obsession relates to the shareholder value channel. This view derives from the satisfaction of three premises: (i) the adoption of "best" corporate governance practices promote the financial interests of shareholders (as measured by the market price of their shares), (ii)

\footnotetext{
http://ssrn.com/abstract=2062429 (finding that environmental labels increased sales to women in retails stores by $8 \%$, but had no effect on male shoppers in outlet stores).

168 Edward Rock, Institutional Investors in Corporate Governance, in OXFORD HANDBOOK OF CORPORATE LAW AND GOVERNANCE (Jeffrey N. Gordon \& Wolf-Georg Ringe eds., forthcoming) (reacting to the 2001 EU Green Paper on institutional investors).

${ }^{169}$ Kahan \& Rock, supra note 11.

${ }^{170} \mathrm{Id}$.

${ }^{171}$ We could label these competing paradigms the "Bebchuk view" and the "Nader view," respectively, in reference to prominent advocates of both prongs of the corporate governance obsession.
} 
firm management practices that promote the financial interests of shareholders maximize general social welfare, and (iii) corporate governance practices promote the financial interests of shareholders at lower cost than other alternatives (such as regulation or the market for corporate control). ${ }^{172}$ Nevertheless, it turns out that each of these premises is highly contested. Let's take this analysis step by step.

A. The link between corporate governance and shareholder value

First, as is the case with other social phenomena, assessing the actual consequences of corporate governance practices on shareholder wealth is difficult, but not intractable. Share prices at least provide a readily observable and reasonable proxy for shareholder welfare, though endogeneity may pose a serious obstacle to causal inferences in corporate governance. ${ }^{173}$ Still, as previously mentioned, the finance literature on the effects of specific corporate governance practices is so voluminous that not even specific review articles can cover much ground. ${ }^{174}$ Such an overarching evaluation is evidently outside the scope of this Article.

For our purposes, suffice it to say that there are important empirical studies suggesting that at least some corporate governance practices appear to have a positive effect on firm performance. ${ }^{175}$ Nevertheless, the empirical evidence that the key prescriptions of the corporate governance obsession - enhanced board independence and greater shareholder empowerment - increase shareholder value is not entirely conclusive. $^{176}$

\section{B. The link between shareholder value and social welfare}

Leaving aside the empirical ambiguities surrounding the effect of corporate governance practices on share value, it remains critical to examine the underpinnings of the widely held view that equates shareholder value maximization with social welfare maximization. In other words, as put by William Bratton and Michael Wachter, what makes shareholder wealth maximization "a key that unlocks the door to making the

\footnotetext{
${ }^{172}$ For a detailed account (and critique) of the different rationales for shareholder primacy, see Ronald Chen \& Jon Hanson, The Illusion of Law: The Legitimating Schemas of Modern Policy and Corporate Law, 103 MiCH. L. REV. 1 (2004).

${ }^{173}$ For a discussion of this problem, see M. Babajide Wintoki, James S. Linck \& Jeffry M. Netter, Endogeneity and the Dynamics of Internal Corporate Governance, 105 J. FIN. ECON. 581 (2012).

${ }^{174}$ Diane K. Denis, Twenty-Five Years of Corporate Governance Research . . . and Counting, 10 REV. FIN. ECON. 191, 191 (2001) ("The sheer volume of papers that have been written on the subject makes the prospect of surveying corporate governance a daunting task").

${ }^{175}$ See, e.g., Lucian Bebchuk, Alma Cohen \& Allen Ferrel, What Matters in Corporate Governance?, 22 REV. FIN. STUD. 783 (2009) (finding that certain entrenching provisions are correlated with lower Tobin's $Q$ and shareholder returns in the 1990s); Sanjai Bhagat \& Brian Bolton, Corporate Governance and Firm Performance, 14 J. CORP. FIN. 257 (2008) (finding that certain corporate governance practices are correlated with better operating performance).

176 See, e.g., Romano, supra note 18; Klausner, supra note 19; and note 72 and accompanying text. See also K. J. Martijn Cremers, Lubomir P. Litov \& Simone M. Sepe, Staggered Boards and Firm Value, Revisited (Working Paper, 2013), http://ssrn.com/abstract=2364165 (finding a positive association between staggered boards and firm value)
} 
world a better place”? ${ }^{177}$ There are at least two possible answers to this question. ${ }^{178}$

The first and foremost answer in the academic literature is based on the conception of the firm as a "nexus of contracts"179 and the related lessons of transaction cost economics. In this view, the corporation is simply an engine of efficiency. Shareholders - like workers, consumers, creditors, and suppliers - have a contractual relationship with the firm. But while these other groups have fixed claims against the firm, shareholders have no more than a residual claim - that is, shareholders only receive whatever is left after all other claimants have been satisfied. Moreover, unlike investors in other types of business entities, shareholders' investment is "locked in" the corporation, as they lack the ability to exit by forcing the liquidation of the firm's assets. ${ }^{180}$

It is the unique nature of their interest in the firm that makes it particularly costly for shareholders to protect their interests through contract alone. Consequently, efficiency requires corporate law and policy to favor the interests of shareholders - not because these interests are intrinsically superior to those of other constituencies, but rather because workers, consumers, creditors and suppliers are able to protect their interests through contract terms at lower cost. ${ }^{181}$ As is the case with respect to individuals, the externalities imposed by the firm on outsiders should be addressed by government regulations.

The foregoing view, although dominant, has always had its critics in legal academia, including among law-and-economics scholars. ${ }^{182}$ But it was the financial

${ }^{177}$ William W. Bratton \& Michael L. Wachter, Shareholders and Social Welfare, 36 SEATTLE U. L. REV. 489, 489 (2013).

178 Still another possible argument in favor of shareholder primacy has to do with dynamic efficiency that is, through its effect on capital allocation and financial development and, consequently, on financial development. See, e.g., Claessens \& Yurtoglu, supra note 1 (suggesting the existence of such a connection).

${ }^{179}$ Jensen \& Meckling, supra note 30.

180 Hansmann et al., supra note 21 (describing the advent of what they call "entity shielding”); Lynn Stout, On the Nature of the Corporations, 1 U. ILL. L. REV. 253 (2005) (depicting the ability to lock in shareholders' initial capital contributions as the defining characteristic of the corporate form).

181 See, e.g., John Armour, Henry Hansmann \& Reinier Kraakman, What Is Corporate Law?, in ANATOMY 28, supra note 29; Williamson, supra note 41, at 1228 ("By its very nature, the contractual relationship between the shareholders and firm is difficult to safeguard... For this reason, the board of directors should be regarded principally as a governance instrument of the shareholders”).

182 See, e.g., Margaret Blair \& Lynn A. Stout, A Team Production Theory of Corporate Law, 85 VA. L. REV. 247 (1999) (arguing that the main problem the corporate form seeks to address is one of "team production," which, in turn, requires directors to maximize the joint welfare of all corporate stakeholders). The debate about the interests that corporate management should serve dates back to the celebrated Berle-Dodd debates of the early 1930s. For the first and more influential installments of this debate, see Adolph A. Berle, Corporate Powers as Powers in Trust, 44 HARV. L. REV. 1049 (1931) (arguing that directors should act in the interests of shareholders alone), and E. Merrick Dodd, For Whom Are Corporate Managers Trustees?, 45 HARV. L. REV. 1145, 1148 (1932) (viewing the "business corporation as an economic institution which has a social service as well as a profit-making function”). For more recent work recasting the debate in terms of the corporatist ideology prevailing at the time, see William W. Bratton \& Michael L. Wachter, Shareholder Primacy’s Corporatist Origins: Adolf Berle and The Modern Corporation, 34 J. CORP. L. 99 (2008). 
crisis of 2008 - and its immense costs to taxpayers and deleterious implications for macroeconomic performance - that has disseminated growing skepticism of the shareholder primacy norm. At least with respect to financial institutions, the pursuit of shareholder value maximization no longer appears conducive to the promotion of social welfare even to advocates of shareholder primacy. ${ }^{183}$

A second and more politically popular version of the defense of investor interests posits that in a "society of shareholders" 184 where a major portion of the population is invested in stock markets, shareholder wealth provides a reasonable approximation of social welfare. This view has gained traction in the last decades. Prompted by a shift from defined benefit to defined distribution pension plans, ${ }^{185} \mathrm{a}$ large portion of the middle class came to rely on stock markets for retirement savings. The fraction of U.S. households that owned corporate equities soared from one-fifth in 1983 to one-half in 2005 . $^{186}$ Accordingly, politicians seized on the opportunity to equate stock market performance to the interests of the American public. ${ }^{187}$

Yet for all of the political appeal associated with the image of an ownership society, closer scrutiny of the distribution of shareholdings across the general population provides a markedly different picture. As pointed out by Bratton and Wachter, data from the Federal Reserve Board's Survey of Consumer Finances and the Internal Revenue Service show that "even as shareholding has diffused downward to lower income individuals, the shareholders' overall socioeconomic status has remained largely unchanged," with the modal shareholder being old, white, and in the top $1 \%$ of the income distribution. ${ }^{188}$ The concentration of equity ownership remains astoundingly high: the top $10 \%$ owns $81 \%$ of the stock, while the bottom $80 \%$ accounts for only $9 \%$ of shares. ${ }^{189}$ Accordingly, there is little immediate overlap between the interests of shareholders and those of society as a whole.

\section{(ii) Other channels}

Whereas the confidence in the link between shareholder value and social welfare has dwindled in recent years, the view that corporate governance can contribute to

\footnotetext{
183 See note 124 and accompanying text. This view derives from the same theoretical perspective that defends shareholder value maximization for non-banks, but acknowledges that deposit insurance and "too-big-to-fail" policies make taxpayers, rather than shareholders, residual claimants in failing financial institutions. For a broader reappraisal of shareholder primacy prompted by the global financial crisis, see Simon Deakin, Corporate Governance and Financial Crisis in the Long Run (Ctr. for Bus. Research, University of Cambridge Working Paper No. 417, 2010), http://www.cbr.cam.ac.uk/pdf/WP417.pdf.

${ }^{184}$ It is revealing that President Clinton justified its plea to Congress to renew his "fast-track-tradenegotiation authority" by claiming that "I think it will have a very positive impact on the stock market here and around the world.” Jacob Weisberg, Whatever Happened to Politics?; United Shareholders Of America, N.Y. TIMES, Jan. 25, 1998.

${ }^{185}$ Gelter, supra note 16.

${ }^{186}$ Bratton \& Wachter, supra note 177 , at 510.

${ }^{187} \mathrm{Id}$. at 512 . See also note 184 supra and accompanying text.

${ }^{188}$ Bratton \& Wachter, supra note 177 , at 491.

${ }^{189}$ Id. at 518. For the original analysis, see Edward N. Wolff, Recent Trends in Household Wealth in the United States: Rising Debt and the Middle Class Squeeze - An Update to 2007 (Levy Econ. Inst., Working Paper No. 589, 2010), http://www.levyinstitute.org/publications/?docid=1235.
} 
social welfare in other ways has correspondingly gained prominence. Nonetheless, in contrast to the large number of works investigating the relationship between corporate governance and performance, the literature on the impact of corporate governance on other metrics of social well-being is scant. ${ }^{190}$ This scarcity is in part due to the fact that the spike in interest in the topic has been quite recent and in part due to the inherent difficulty in measuring the impact of corporate governance on other social metrics.

But if the empirical evidence is sparse, there are good theoretical reasons to give us pause about the recent uses of corporate governance to tackle broad societal concerns. If evaluating the effect of different corporate policies on aggregate welfare is exceedingly challenging for researchers, the difficulty is only compounded for corporate directors, who will likely lack the information, expertise, and time to engage in such calculations. It is precisely for this reason that scholars have long warned against the imposition on the board of directors of wide-ranging duties to multiple constituencies. Because of the inherent difficulty in measuring performance against multiple objectives, a likely unintended consequence would be to increase directors' to pursue their own interests. ${ }^{191}$

Nor is the prospect of direct shareholder involvement in corporate governance sufficient to overcome this problem. The rise of institutional investor ownership has created an extra layer of agency costs - which Ronald Gilson and Jeffrey Gordon have dubbed the "agency costs of agency capitalism.",192 The pursuit of multiple bottom lines makes it at least as difficult to monitor the performance of institutional investors as it does with respect to corporate directors.

Yet even if institutional investors were perfect agents of the beneficial owners of the shares, there would still be a fundamental problem in the use of corporate governance to further social interests. The intractable difficulty is the ultimate misalignment between the interests of shareholders and those of society as a whole. Because the distribution of share ownership in the general population is highly concentrated, ${ }^{193}$ shareholders have few incentives - and questionable legitimacy ${ }^{194}-$ to

\footnotetext{
${ }^{190}$ For examples of this line of work, see Ola Sjöberg, Corporate Governance and Earnings Inequality in the OECD Countries 1979-2000, 25 EUR. SOC. REV. 519 (2009) (linking corporate governance institutions to stratification processes); Judith L. Walls, Pascual Berrone \& Phillip H. Phan, Corporate Governance and Environmental Performance: Is There Really a Link?, 33 STRATEGIC MGMT. J. 885 (2012) (finding that companies with powerful CEOs who also served as board chair had more environmental strengths); Renee B. Adams \& Vanitha Ragunathan, Lehman Sisters (Working Paper, 2013), http://ssrn.com/abstract=2380036 (finding no relationship between the greater presence of female directors prior to the crisis and firm risk).

191 Jonathan R. Macey, An Economic Analysis of the Various Rationales for Making Shareholders the Exclusive Beneficiaries of Corporate Fiduciary Duties, 21 STETSON L. REV. 23, 31 (1991). See also Luca Enriques, Henry Hansmann \& Reinier Kraakman, The Basic Governance Structure: Minority Shareholders and Non-Shareholders Constituencies, in ANATOMY 103, supra note 29 ("even fair-minded directors are unlikely to know how best to distribute surplus among multiple corporate constituencies”).

${ }^{192}$ Gilson \& Gordon, supra note 15.

${ }^{193}$ See notes 188-189 supra and accompanying text.

${ }^{194}$ Bratton \& Wachter, supra note 177, at 525. For a critique along these lines of board involvement in distributional issues, see Ronald J. Gilson \& Reinier Kraakman, Clark's Treatise on Corporate Law:
} 
act as stewards for the public good. Hence, the external constraints provided by market forces and regulation may still be needed.

\section{Corporate governance and its alternatives}

In any serious analysis of the merits of the corporate governance obsession, it is not enough to assess the effects of corporate governance on shareholder value or social welfare; it is also critical to examine how corporate governance fares compared to alternative mechanisms to further the same objectives, such as strengthening government regulation and unleashing market forces. For instance, one might conclude that corporate governance mandates are not nearly as effective in promoting shareholder value as the unobstructed operation of the market for corporate control, ${ }^{195}$ that strict prudential regulation is more likely to prevent future financial crises than relying on "say on pay" or independent compensation committees, ${ }^{196}$ or that the tax and transfer system is a more effective way to fight soaring inequality than meddling with executive compensation. Yet any adequate analysis of these different alternatives will inevitably be context specific. This stands in sharp contrast to the corporate governance solution, an off-the-rack response that is not well matched to the specific problems at stake.

The importance of evaluating corporate governance in view of its alternatives has at times been overlooked. Instead, advocates have over time defended corporate governance practices based on a "“chicken soup' type of argument - ('it can't hurt, but might help')."197 Nevertheless, even if the adoption of such practices does not harm companies or society (a big "if"), the obsession with corporate governance may still be harmful to the extent that it crowds out more meaningful modes of reform. Just like chicken soup, the relentless emphasis on corporate governance may hurt if it ends up discouraging the patient to seek other remedies for a real problem.

It turns out, however, that a distinctive feature of the obsession with corporate governance, and a major source of its appeal, is its role as a substitute for government action. The corporate governance agenda is repeatedly used to replace regulatory alternatives - and purposefully so. The fact that corporate governance might crowd out the intellectual agenda and policy space may be problematic insofar as corporate governance proves to be less effective than alternative interventions. As a result, the advantages of corporate governance in political palatability need to be traded off against

Filling Manning's Empty Towers, 31 J. CORP. L. 599, 604 (2006) (raising "the the ugly problem of political legitimacy" - "do we want to encourage an institution that is disproportionately white, male and conservative to make social policy?”). See also Velikonja, supra note 72 (arguing that institutional investors support enhanced board independence precisely to fend off more meaningful reforms).

${ }^{195}$ See, e.g., MACEY, supra note 12.

${ }^{196}$ See, e.g., Bebchuk \& Spamann, supra note 124.

${ }^{197}$ For an application of this argument to the separation of roles of board chair and CEO, see Millstein Ctr., supra note 126, at 19; Constance E. Bagley \& Richard H. Koppes, Leader of the Pack: A Proposal for Disclosure of Board Leadership Structur, 34 SAN DIEGo L. REV. 149, 166 (1997). For the original reference to this argument in the context of "just say no" campaigns by stockholders, see Joseph A. Grundfest, Just Vote No: A Minimalist Strategy for Dealing with Barbarians Inside the Gate, 45 STAN. L. REV. 857, 868 (1993). 
this crowd-out effect.

\section{Conclusion: The Future of the Corporate Governance Obsession}

Interest in corporate governance soared as the government retreated in the last decades. Ralph Nader, previously self-described as an "adversary of capitalism" has joined the ranks of activist investors - a role he regards as a "natural extension of his work" in a world in which "deregulation is rampant." 198 Whether the obsession with corporate governance will endure in the future remains an open question. There are at least two key challenges to the agenda's continued vitality, one stemming from its success and another one from its limitations.

A first threat to the corporate governance obsession comes from its wide acceptance, as evidenced by the rising levels of adoption of "best practices" that made up the traditional repertoire of advocates or policy entrepreneurs. ${ }^{199}$ As recently described in a memorandum by the celebrated law firm of Wachtell, Lipton, Rosen \& Katz, a vocal corporate governance critic,

"In many respects, the relentless drive to adopt corporate governance mandates seems to have reached a plateau: essentially all of the prescribed 'best practices'-including say-on-pay, the dismantling of takeover defenses, majority voting in the election of directors and the declassification of board structures-have been codified in rules and regulations or voluntarily adopted by a majority of S\&P 500 companies. Only 11 percent of S\&P 500 companies have a classified board, 8 percent have a poison pill and 6 percent have not adopted a majority vote or plurality-vote-plus-resignation standard to elect directors. The activists' 'best practices' of yesterday have become the standard practices of today. While proxy advisors and other stakeholders in the corporate governance industry will undoubtedly continue to propose new mandates, we are currently in a period of relative stasis as compared to the sea change that began with the Sarbanes-Oxley Act and unfolded over the last decade."200

To a significant extent, the dreams of yesterday's corporate governance advocates have come true. Boards have never been so independent. We are currently in the golden age of shareholder activism. Nevertheless, the implementation of past prescriptions does not, by itself, entail the demise of the corporate governance obsession.

\footnotetext{
198 Steven Davidoff Solomon, Nader, an Adversary of Capitalism, Now Fights as an Investor, N.Y. TimeS, Jan. 15, 2014, at B7.

${ }^{199}$ On this point, see Cheffins, supra note 15, at 59 (quoting a corporate responsibility consultant who argued in 2010 that corporate governance was "dead. Gone. Pffft").

${ }^{200}$ Martin Lipton, Steven A. Rosenblum \& Karessa L. Cain, Some Thoughts for Boards of Directors in 2014, Nov. 27, 2013, http://www.wlrk.com/docs/ThoughtsforBoardsofDirectorsin2014.pdf.
} 
Although the central issues of board independence and shareholder democracy have been fairly stable since the 1970s, the corporate governance movement has also shown a remarkable tendency to reinvent itself at the margins. As previous frontiers are overcome, new ones emerge. For instance, as boards become increasingly independent, the requirements for independence become more exacting - as is the case with respect to the new debates around board refreshment and tenure limits to board service. ${ }^{201}$ But even if the corporate governance industry is able to foster new frontiers, it is plausible that, in the process of delving into further technicalities, ${ }^{202}$ the agenda may lose part of its political and symbolic appeal.

A more credible threat to the corporate governance obsession comes from the loss of faith in its theoretical underpinnings: the distrust of government and the related belief that the private sector can govern itself. ${ }^{203}$ Since the financial crisis, even the most ardent corporate governance proponents have come to acknowledge its shortcomings and argue for regulatory responses. ${ }^{204}$

Whatever the future holds for the corporate governance obsession, its lasting grip on public discourse makes the theme ripe for further scrutiny. Understanding its roots and premises is but a first step. Future research into the merits of different corporate governance mandates should not only examine the costs and benefits of these practices in isolation, but also account for the extent to which the metaphor of the selfgoverning corporation may crowd out more effective modes of intervention for the public good.

\footnotetext{
${ }^{201} I d$.

${ }^{202}$ Kahan \& Rock, supra note 11, at 2 (arguing that "there is a corporate governance reform 'industry' that demands activity to keep itself going”).

${ }^{203}$ In the words of Robert Monks, one of the founders of the corporate governance movement, "[m]uch hard activist work has gone into furthering the ideals of corporate governance by so many who believed corporations could responsibly regulate themselves, but 'self-restraint' proved largely to be no restraint." Robert Monks, Governance at a Crossroads: A Personal Perspective, 8 INT. J. Disclosure \& GOVERNANCE 62 (2011).

${ }^{204}$ For a paradigmatic example of this shift, see Bebchuk \& Spamann, supra note 124 (defending the inefficacy of corporate governance reforms and arguing for the regulation of bankers' pay). See also John Armour \& Jeffrey Gordon, Systemic Harms and Shareholder Value (ECGI, Law Working Paper No. 222, 2013), http://ssrn.com/abstract=2307959 (arguing for the imposition of stricter liability rules for directors and officers at financial firms).
} 